\title{
Mid-Holocene Antarctic sea-ice increase driven by marine ice sheet retreat
}

\author{
Kate E. Ashley ${ }^{1}$, Robert McKay ${ }^{2}$, Johan Etourneau ${ }^{3,6}$, Francisco J. Jimenez-Espejo ${ }^{3,4}$, Alan Condron ${ }^{5}$, Anna Albot ${ }^{2}$, \\ Xavier Crosta $^{6}$, Christina Riesselman ${ }^{7,8}$, Osamu Seki ${ }^{9}$, Guillaume Massé $^{10}$, Nicholas R. Golledge ${ }^{2,11}$, \\ Edward Gasson $^{12}$, Daniel P. Lowry ${ }^{2,11}$, Nicholas E. Barrand ${ }^{1}$, Katelyn Johnson ${ }^{2,11}$, Nancy Bertler ${ }^{2,11}$, \\ Carlota Escutia $^{3}$, Robert Dunbar ${ }^{13}$, and James A. Bendle ${ }^{1}$ \\ ${ }^{1}$ School of Geography, Earth and Environmental Sciences, University of Birmingham, Edgbaston, Birmingham, B15 2TT, UK \\ ${ }^{2}$ Antarctic Research Centre, Victoria University of Wellington, Wellington 6140, New Zealand \\ ${ }^{3}$ EPHE/PSL Research University, 4-14 rue Ferrus, 75014 Paris, France \\ ${ }^{4}$ Department of Biogeochemistry, Japan Agency for Marine-Earth Science and Technology (JAMSTEC), \\ Yokosuka 237-0061, Japan \\ ${ }^{5}$ Department of Geology and Geophysics, Woods Hole Oceanographic Institution, Woods Hole, MA 02543, USA \\ ${ }^{6}$ UMR 5805 EPOC, Université de Bordeaux, CNRS, EPHE, 33615 Pessac, France \\ ${ }^{7}$ Department of Geology, University of Otago, Dunedin 9016, New Zealand \\ ${ }^{8}$ Department of Marine Science, University of Otago, Dunedin 9016, New Zealand \\ ${ }^{9}$ Institite of Low Temperature Science, Hokkaido University, Sapporo 060-0819, Hokkaido, Japan \\ ${ }^{10}$ TAKUVIK, UMI 3376 UL/CNRS, Université Laval, 1045 avenue de la Médecine, Quebec City, Quebec, G1V 0A6, Canada \\ ${ }^{11}$ GNS Science, Avalon, Lower Hutt 5011, New Zealand \\ ${ }^{12}$ School of Geographical Sciences, University of Bristol, Bristol, BS8 1RL, UK \\ ${ }^{13}$ Department of Environmental Earth Systems Science, Stanford University, Stanford, A 94305, California, USA
}

Correspondence: James A. Bendle (j.bendle@bham.ac.uk)

Received: 16 January 2020 - Discussion started: 26 February 2020

Revised: 15 October 2020 - Accepted: 16 October 2020 - Published: 5 January 2021

\begin{abstract}
Over recent decades Antarctic sea-ice extent has increased, alongside widespread ice shelf thinning and freshening of waters along the Antarctic margin. In contrast, Earth system models generally simulate a decrease in sea ice. Circulation of water masses beneath large-cavity ice shelves is not included in current Earth System models and may be a driver of this phenomena. We examine a Holocene sediment core off East Antarctica that records the Neoglacial transition, the last major baseline shift of Antarctic sea ice, and part of a late-Holocene global cooling trend. We provide a multiproxy record of Holocene glacial meltwater input, sediment transport, and sea-ice variability. Our record, supported by high-resolution ocean modelling, shows that a rapid Antarctic sea-ice increase during the mid-Holocene $(\sim 4.5 \mathrm{ka})$ occurred against a backdrop of increasing glacial meltwater input and gradual climate warming. We suggest that midHolocene ice shelf cavity expansion led to cooling of surface
\end{abstract}

waters and sea-ice growth that slowed basal ice shelf melting. Incorporating this feedback mechanism into global climate models will be important for future projections of Antarctic changes.

\section{Introduction}

Ice shelves and sea ice are intrinsically linked and represent fundamental components of the global climate system, impacting ice sheet dynamics, large-scale ocean circulation, and the Southern Ocean biosphere. Antarctic ice shelves with large sub-shelf cavities (e.g. Ross, Filchner-Ronne) play a key role in regional sea-ice variations, by cooling and freshening surface ocean waters for hundreds of kilometres beyond the ice shelf edge (Hellmer, 2004; Hughes et al., 2014). Antarctic sea ice has expanded over the past few decades, 
particularly in the western Ross Sea region (Turner et al., 2016), alongside widespread thinning of ice shelves (Paolo et al., 2015) and freshening along the Antarctic margin (Jacobs et al., 2002; Aoki et al., 2013). The drivers and feedbacks involved in these decadal trends are still poorly understood, hampered by the sparse and short-term nature of meteorological, oceanographic and glaciological observations (Jones et al., 2016), and thus establishing the long-term trajectory for East Antarctic sea ice on the background of accelerated ice sheet loss remains a challenge. Marine sediment cores provide a longer-term perspective and highlight a major baseline shift in coastal sea ice at $\sim 4.5 \mathrm{ka}$ (Steig et al., 1998; Crosta et al., 2008; Denis et al., 2010), which characterizes the mid-Holocene "Neoglacial" transition in the Antarctic. A mechanistic driver for this climate shift currently remains unresolved, but we propose that two interrelated aspects of the last deglaciation are significantly underrepresented in current models of this transition: (i) the retreat of grounded ice sheets from the continental shelves of Antarctica, and (ii) the subsequent development of large ice shelf cavities during the Holocene. Both factors would significantly alter water mass formation on Antarctica's continental shelves, which today are major source regions of Antarctic Bottom Water (AABW) and Antarctic Surface Water (AASW). These interrelated processes are underrepresented in coupled oceanatmosphere models, which currently do not simulate the timing, magnitude, and rapid onset of the Neoglacial (see the Supplement).

Integrated Ocean Drilling Program (IODP) Expedition 318 cored a $171 \mathrm{~m}$ thick deposit of laminated diatomaceous ooze at Site U1357 offshore Adélie Land (Fig. 1) deposited over the past 11400 years. Here, we present a new Holocene record of glacial meltwater, sedimentary input, and local seaice concentrations from Site U1357 using compound-specific hydrogen isotopes of fatty acid biomarkers $\left(\delta^{2} \mathrm{H}_{\mathrm{FA}}\right)$, terrigenous grain size (mud percent, sorting), natural gamma radiation, biogenic silica accumulation, highly-branched isoprenoid alkenes (HBIs), and $\mathrm{Ba}$ /Ti ratios (Figs. 4 and 5).

We interpret $\delta^{2} \mathrm{H}_{\mathrm{FA}}$ (Fig. 4a) fluctuations in Adélie Drift sediments as a record of meltwater input from isotopicallydepleted glacial ice. Antarctic glacial ice is highly depleted in ${ }^{2} \mathrm{H}$ compared to ocean water, thus creating highly contrasting endmember values for the two major $\mathrm{H}$ source pools. Grain size, natural gamma radiation (NGR), and terrigenous and biosiliceous mass accumulation rates (MARs) reflect changing sediment delivery either driven via local glacial meltwater discharge or advection of suspended sediment by oceanic currents. The diene/triene HBI ratio is used as a proxy for coastal sea-ice presence (Massé et al., 2011). Ba/Ti enrichment is considered to reflect enhanced primary productivity. These records allow a unique opportunity to reconstruct the magnitude of the coupled response of the ocean and ice sheet during the Neoglacial transition. Details on all proxies and associated uncertainties can be found in Sect. S2 of the Supplement.

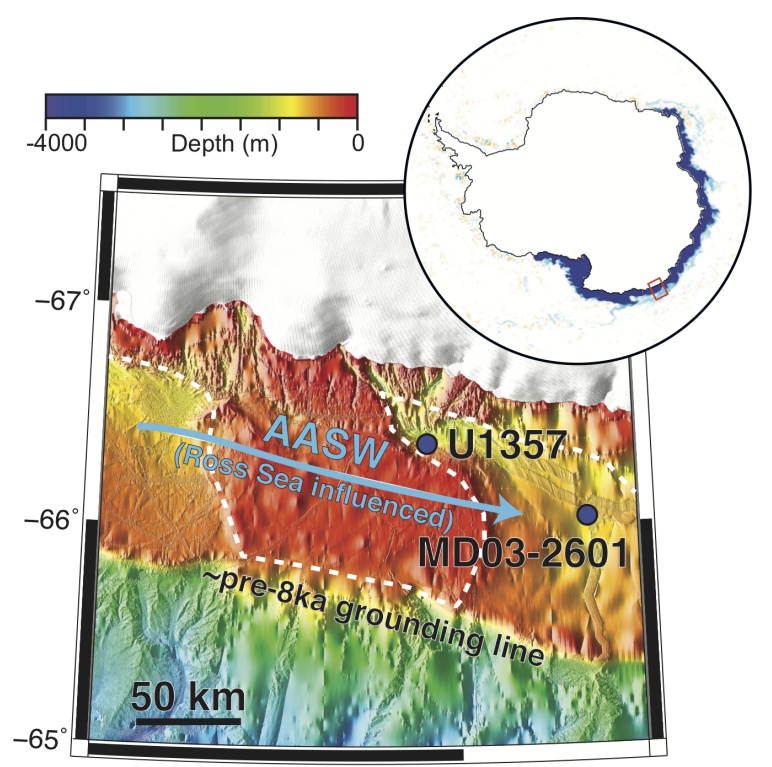

Figure 1. Location of sites U1357 and MD03-2601 (blue dots). The ice sheet grounding line formed a calving-bay environment (dashed white line) prior to $11.4 \mathrm{ka}$, but since at least $8.2 \mathrm{ka}$ Antarctic Surface Water flow is largely advected from the Ross Sea (blue line). The inset map shows the pathway of freshwater (dark blue) after 1 year of $1 \mathrm{~Sv}$ meltwater released from along the edge of the Ross Ice Shelf in a model simulation.

\section{Materials and methods}

\subsection{Organic geochemical analyses}

\subsubsection{Fatty acid extraction}

Lipid extraction of sediment samples was performed at the Royal Netherlands Institute for Sea Research (NIOZ). Freeze-dried and homogenized samples were extracted by Dionex $^{\mathrm{TM}}$ accelerated solvent extraction (DIONEX ASE 200) using a mixture of dichloromethane (DCM)/methanol $(\mathrm{MeOH})(9: 1, v / v)$ at a temperature of $100^{\circ} \mathrm{C}$ and a pressure of $7.6 \times 10^{6} \mathrm{~Pa}$ (Kim et al., 2010).

Compound separation was undertaken at University of Glasgow, UK. The total lipid extract was separated over an aminopropyl silica gel column and the total acid fraction was eluted into an $8 \mathrm{~mL}$ vial with $4 \%$ acetic acid in ethylether solution (Huang et al., 1999). Derivatization to fatty acid methyl esters was achieved by adding $200 \mu \mathrm{L}$ of $\mathrm{MeOH}$ containing $14 \% v / v$ boron trifluoride to the $8 \mathrm{~mL}$ vial containing the total acid fraction (TAF). Fatty acid methyl esther (FAMES) were recovered and cleaned up by eluting through a pre-cleaned $3 \mathrm{~cm}$ silica gel column $(60 \mathrm{~A} ; 35-70)$ with $4 \mathrm{~mL}$ of hexane and $4 \mathrm{ml}$ of DCM (containing the FAMES). $\delta^{2} \mathrm{H}$ values indicate depletion against the international standards: Vienna Pee Dee Belemnite (V-PDB) is the standard for $\delta 13 \mathrm{C}$, and Vienna Standard Mean Ocean Water (V-SMOW) is the standard for $\delta^{2} \mathrm{H}$. 


\subsubsection{Fatty acid hydrogen isotope analysis}

Compound-specific hydrogen isotope analyses of FAMES were performed at the Institute of Low Temperature Science, Hokkaido University. $\delta^{2} \mathrm{H}$ values were obtained using a CS-IRMS system with a HP 6890 gas chromatograph and a ThermoQuest Finnigan MAT Delta Plus XL mass spectrometer (MS). Separation of the FAMES was achieved with a HP-5 MS fused silica capillary column $(30 \mathrm{~m} \times 0.32 \mathrm{~mm}$ i.d., film thickness of $0.25 \mu \mathrm{m}$ ) with a cooled on-column injector. An $n$-alkane and a reference gas whose isotopic values were known was co-injected with the samples as an internal isotopic standard for $\delta^{2} \mathrm{H}$. A laboratory-standard (Mix F8 of FAMES from Indiana University) containing $\mathrm{C}_{10}$ $\mathrm{C}_{30}$ FAMES was analysed daily to check the accuracy and the drift of the instrument and to normalize the data to the SMOW-SLAP isotopic scale. The $\mathrm{H}^{3+}$ factor was measured every $3 \mathrm{~d}$.

\subsubsection{HBls}

Highly branched isoprenoid (HBI) alkenes were extracted at Laboratoire d'Océanographie et du Climat: Experimentations et Approches Numériques (LOCEAN), separately from the fatty acids, using a mixture of $9 \mathrm{~mL} \mathrm{CH}_{2} \mathrm{Cl}_{2} / \mathrm{MeOH}$ $(2: 1, v: v)$ to which 7 hexyl nonadecane $(\mathrm{m} / \mathrm{z} 266)$ was added as an internal standard, following the Belt et al. (2007) and Massé et al. (2011) protocols. Several sonication and centrifugation steps were applied in order to properly extract the selected compounds (Etourneau et al., 2013). After drying with $\mathrm{N}_{2}$ at $35^{\circ} \mathrm{C}$, the total lipid extract was fractionated over a silica column into an apolar and a polar fraction using $3 \mathrm{~mL}$ hexane and $6 \mathrm{~mL} \mathrm{CH}_{2} \mathrm{Cl}_{2} / \mathrm{MeOH}(1: 1, v: v)$, respectively. HBIs were obtained from the apolar fraction by the fractionation over a silica column using hexane as eluent following the procedures reported by Belt et al. (2007) and Massé et al. (2011). After removing the solvent with $\mathrm{N}_{2}$ at $35^{\circ} \mathrm{C}$, elemental sulfur was removed using the TBA (Tetrabutylammonium) sulfite method (Jensen et al., 1977; Riis and Babel, 1999). The obtained hydrocarbon fraction was analysed within an Agilent 7890A gas chromatograph (GC) fitted with $30 \mathrm{~m}$ fused silica Agilent J\&C GC column ( $0.25 \mathrm{~mm}$ i.d., $0.25 \mu \mathrm{m}$ film thickness), coupled to an Agilent 5975C Series mass selective detector (MSD). Spectra were collected using the Agilent MS-Chemstation software. Individual HBIs were identified on the basis of comparison between their GC retention times and mass spectra with those of previously authenticated HBIs (Johns et al., 1999) using the Mass Hunter software. Values are expressed as concentration relative to the internal standard.

\subsection{Inorganic geochemical analysis and electronic microscopy}

Major element concentrations were obtained using X-Ray Fluorescence Scanner on 412 analyses measured directly over undisturbed sediment sections. The bulk major element composition included in this study was measured between sections U1357B-1H-2 to U1357-19H-5 continuously each $50 \mathrm{~cm}$. We used an Avaatech X-ray fluorescence (XRFScanner) core scanner at the IODP-Core Repository/Texas A\&M University laboratories (USA) during December 2010. Non-destructive XRF core-scanning measurements were performed over a $1 \mathrm{~cm}^{2}$ area with slit size of $10 \mathrm{~mm}$, a current of $0.8 \mathrm{~mA}$, and sampling time of $45 \mathrm{~s}$ at $10 \mathrm{kV}$ in order to measure the relative content of titanium (Ti) and barium (Ba).

Field emission scanning electron microscopy (FESEM) images and corresponding spectrum were obtained with an AURIGA FIB-FESEM Carl Zeiss SMT at Centro de Instrumentación Científica, Granada University, Spain

\subsection{Grain size analyses}

A total of 341 samples were prepared for grain size analysis. Samples were treated for removal of biogenic opal with a $1 \mathrm{M}$ sodium hydroxide $\mathrm{NaOH}$ solution and incubated in a water bath at $80^{\circ} \mathrm{C}$ for $24 \mathrm{~h}$. This procedure was repeated twice due to an incomplete dissolution of diatoms observed in smear slides. The samples were then treated with $\mathrm{H}_{2} \mathrm{O}_{2}$ to remove organic material at $80^{\circ} \mathrm{C}$ for $24 \mathrm{~h}$. Samples were measured using a Beckman Coulter LS 13320 Laser Diffraction Particle Size Analyser (LPSA). Prior to grain size analysis, $\sim 30 \mathrm{~mL}$ of $0.5 \mathrm{~g} / \mathrm{L}$ Calgon (sodium hexametaphosphate) was added to the samples and sonicated and stirred in order to disperse the grains and prevent clumping.

\subsection{Biogenic silica}

Biogenic silica concentrations (wt \% BSi) were measured on 349 discrete samples using a molybdate blue spectrophotometric method modified from (Strickland and Parsons, 1970; DeMaster, 1981). Analytical runs included replicates from the previous sample group and from within the run, and each run was controlled by 10 standards and a blank with dissolved silica concentrations ranging from 0 to $1200 \mu \mathrm{M}$. For each analysis, $\sim 7 \mathrm{mg}$ of dry, homogenized sediment was leached in $0.1 \mathrm{M} \mathrm{NaOH}$ at $85^{\circ} \mathrm{C}$, and sequential aliquots were collected after 2, 3, and $4 \mathrm{~h}$. Following addition of reagents, absorbance of the $812 \mathrm{~nm}$ wavelength was measured using a Shimadzu UV-1800 spectrophotometer. Dissolved silica concentration of each unknown was calculated using the standard curve, and data from the three sampling hours were regressed following the method of DeMaster (1981) to calculate wt $\% \mathrm{BSi}$. In our U1357B samples, wt \% BSi ranges from maximum of $\sim 60 \%$ in early and mid-Holocene light laminae to a minimum of $31 \%$ in late Holocene dark laminae. The average standard deviation of replicate measurements is $0.5 \%$. 


\subsection{Model simulations}

All numerical calculations were performed using the Massachusetts Institute of Technology general circulation model (MITgcm) (Marshall et al., 1997): a three-dimensional, ocean sea ice, hydrostatic, primitive equation model. The experiments presented here were integrated on a global domain projected onto a cube-sphere grid to permit a relatively even grid spacing and to avoid polar singularities (Adcroft et al., 2004; Condron and Winsor, 2012). The ocean grid has a mean, eddy-permitting, horizontal grid spacing of $1 / 6^{\circ}$ $(18 \mathrm{~km})$ with 50 vertical levels ranging in thickness from $10 \mathrm{~m}$ near the surface to approximately $450 \mathrm{~m}$ at the maximum model depth. The ocean model is coupled to a seaice model in which ice motion is driven by forces generated by the wind, ocean, Coriolis force, and surface elevation of the ocean, while internal ice stresses are calculated using a viscous-plastic (VP) rheology, as described in Zhang and Hibler (1997). In all experiments, the numerical model is configured to simulate present-day (modern) conditions: atmospheric forcings (wind, radiation, rain, humidity, etc.) are prescribed using 6-hourly climatological (1979-2000) data from the ERA-40 reanalysis product produced by the European Centre for Medium-range Weather Forecasts and background rates of runoff from the ice sheet to the ocean are based on the numerical ice sheet model of Pollard and Deconto (2016) integrated over the same period (1979-2000). To study the pathway of meltwater in the ocean, additional fresh (i.e. $0 \mathrm{psu}$ ) water was released into the surface layer of the ocean model at the grid points closest to the front of the Ross Ice Shelf. Five different discharge experiments were performed by releasing meltwater into this region at rates of $0.01 \mathrm{~Sv}\left(\mathrm{~Sv}=10^{6} \mathrm{~m}^{3} / \mathrm{s}\right), 0.05,0.1,0.5$, and $1 \mathrm{~Sv}$ for the entire duration of each experiment $(\sim 3.5$ years $)$.

\section{Environmental setting and interpretation of proxy data}

We utilize a $180 \mathrm{~m}$ thick sediment core that was recovered from the Wilkes Land Margin continental shelf in the Adélie Basin (IODP Site U1357). This core targeted an expanded sediment drift (Adélie Drift) and provides a high-resolution Holocene record of climate variability. Below we provide pertinent details on this unique site and on our application of compound-specific $\delta^{2} \mathrm{H}$ measurements on algal biomarkers as a novel meltwater proxy. Further details on proxy interpretation (Ba/Ti, grain size, HBIs) are given in the Supplement.

\subsection{The Adélie Drift}

Site U1357 is located in the Dumont d'Urville Trough of the Adélie Basin, ca. $35 \mathrm{~km}$ offshore from Adélie Land $\left(66^{\circ} 24.7990^{\prime} \mathrm{S}, 140^{\circ} 25.5705^{\prime} \mathrm{E}\right.$; Fig. 1). This is a $>1000 \mathrm{~m}$ deep, glacially scoured depression on the East Antarctic continental shelf, bounded to the east by the Adélie Bank. Fur- ther east lays the Adélie Depression and the Mertz Bank, the latter located north of the Mertz Glacier floating ice tongue. The Adélie Land region is dissected by several glaciers that could potentially contribute terrigenous sediment into the coastal zone with the core site located $40 \mathrm{~km}$ to the north of the Astrolabe Glacier and ca. 75 and $300 \mathrm{~km}$ northwest of the Zélée and Mertz glaciers, respectively.

The site itself is located within the Dumont d'Urville polynya (DDUP), which has a summer (winter) extent of $13020 \mathrm{~km}^{2}\left(920 \mathrm{~km}^{2}\right)$ but is also directly downwind and downcurrent of the much larger and highly productive Mertz Glacier polynya (MGP) to the east, with a summer (winter) extent of $26600 \mathrm{~km}^{2}\left(591 \mathrm{~km}^{2}\right.$ ) (Arrigo and van Dijken, 2003). The MGP forms as a result of reduced sea-ice westward advection due to the presence of the Mertz Glacier Tongue (Massom et al., 2001) and strong katabatic winds that blow off the Antarctic ice sheet with temperatures below $-30{ }^{\circ} \mathrm{C}$ (Bindoff et al., 2000). Katabatic winds freeze the surface waters and blow newly formed ice away from the coast, making the polynya an efficient sea-ice "factory", with higher rates of sea-ice formation in comparison to nonpolynya ocean areas that undergo seasonal sea-ice formation (Kusahara et al., 2010). The MGP produces $1.3 \%$ of the total Southern Ocean sea-ice volume despite occupying less than $0.1 \%$ of total Antarctic sea-ice extent (Marsland et al., 2004).

As a result of the upwelling polynya environments, the area along the Adélie Coast is characterized by extremely high primary productivity, with the water column known to host significant amounts of phytoplankton, dominated by diatoms (Beans et al., 2008). The Mertz Glacier zone is generally characterized by stratified waters in the summer, due to seasonal ice melt, with these conditions corresponding to the highest phytoplankton biomass. The lack of ice cover means polynyas are the first polar marine systems exposed to spring solar radiation, making them regions of enhanced biological productivity compared to adjacent waters. A considerable amount of resultant sedimentation is focused via the westward-flowing currents from both of these polynyas within the deep, protected Adélie Basin, resulting in a remarkably high sedimentation rate of ca. $1.5-2 \mathrm{~cm} \mathrm{yr}^{-1}$ at Site U1357 (Escutia et al., 2011).

Although biogenic and terrigenous sediment is interpreted to be sourced locally in the Adélie Land region, the mass accumulation rate of these sediments in this drift is associated with the intensity of westward-flowing currents (Sect. S2.2). Critically, these westward currents also act to transport water masses from further afield, and Site U1357 is directly oceanographically downstream of the Ross Sea, meaning the continental shelf in this region receives significant Antarctic Surface Water (ASSW) transported by the Antarctic Slope Current (ASC) and Antarctic Coastal Current from the Ross Sea embayment. Thus, changes in the surface waters of the Ross Sea influence Site U1357. Whitworth et al. (1998) confirm the continuity of the westwardflowing ASC between the Ross Sea and the Wilkes Land 
margin. This flow is largely associated with the Antarctic Slope Front, which reflects the strong density contrast between AASW and Circumpolar Deep Water (CDW). McCartney and Donohue (2007) estimate that the transport in the westward ASC, which links the Ross Sea to the Wilkes Land margin, reaches $76 \mathrm{~Sv}\left(\mathrm{~Sv}=10^{6} \mathrm{~m}^{3} \mathrm{~s}^{-1}\right)$. However, Peña-Molino et al. (2016) measured a highly variable ASC flow at $113^{\circ} \mathrm{E}$ ranging from 0 to $100 \mathrm{~Sv}$ with a mean of 21.2 Sv. This contributes to a cyclonic gyre, which together with the ASC dominate the circulation at Site U1357. The gyre transport is around $35 \mathrm{~Sv}$ and comes mainly from the Ross Sea region, with a lesser contribution from a westward flow associated with the Antarctic Circumpolar Current (McCartney and Donohue, 2007).

\subsection{Site-specific interpretation of $\delta^{2} \mathrm{H}_{\mathrm{FA}}$ as a glacial meltwater proxy}

\subsubsection{Source of fatty acids}

To best interpret the hydrogen isotope signal recorded by the $\mathrm{C}_{18} \mathrm{FA}$, it is important to determine the most likely source these compounds are derived from, and thus the habitat in which they are produced. The $\mathrm{C}_{18} \mathrm{FA}$, however, is known to be produced by a wide range of organisms and so we cannot preclude the possibility of multiple sources, especially in a highly diverse and productive region such as the surface waters of offshore Adélie Land. However, we can attempt to determine the most dominant producer(s), which will help us understand the main signal being recorded by the isotopes.

An analysis of the FAs within eight classes of microalgae by Dalsgaard et al. (2003) (compiling results from multiple studies) showed Cryptophyceae, Chlorophyceae, Prasinophyceae, and Prymnesiophyceae to be the most dominant producers of total $\mathrm{C}_{18}$ FAs. The Bacillariophyceae class, on the other hand, which includes the diatoms, were found to produce only minor amounts of $\mathrm{C}_{18} \mathrm{FA}$, instead synthesizing abundant $\mathrm{C}_{16: 1}$ FAs. Thus, despite the water column offshore Adélie Land being dominated by diatoms, these are unlikely to be a major source of the $\mathrm{C}_{18}$ FA within U1357B (Beans et al., 2008; Riaux-Gobin et al., 2011).

Of the four microalgae classes dominating $\mathrm{C}_{18}$ production (Dalsgaard et al., 2003), species from the Chlorophyceae and Prymnesiophyceae classes have been observed within surface waters offshore Adélie Land after spring sea-ice breakup (Riaux-Gobin et al., 2011). Here, Phaeocystis antarctica of the Prymnesiophytes was found to dominate the surface water phytoplankton community (representing $16 \%$ of the phytoplankton assemblage), whereas Cryptophyceae spp. were found in only minor abundances (Riaux-Gobin et al., 2011). In the Antarctic, Phaeocystis is thought to be the most dominant producer of $\mathrm{C}_{18}$ FAs (Dalsgaard et al., 2003), and thus is likely to be a key producer of the $\mathrm{C}_{18}$ FA in U1357B samples.
To investigate this further, we measured compoundspecific carbon isotopes of the $\mathrm{C}_{18}$ FAs in U1357B samples, which gives an average $\delta^{13} \mathrm{C}$ value of $-29.8 \% \circ \pm 1.0 \%$ ( $n=$ 85). Budge et al. (2008) measured a similar $\delta^{13} \mathrm{C}$ value of $-30.7 \% \circ \pm 0.8 \%$ from $\mathrm{C}_{16}$ FAs derived from Arctic pelagic phytoplankton, while sea-ice algae and higher trophic level organisms all had much higher $\delta^{13} \mathrm{C}$ values (sea-ice algae having values of $-24.0 \% \circ \pm 2.4 \%$ ). Assuming similar values apply for the $\mathrm{C}_{18} \mathrm{FA}$ and for organisms within the water column at our site, this suggests that our $\mathrm{C}_{18} \mathrm{FA}$ is predominantly derived from pelagic phytoplankton.

Furthermore, $\delta^{13} \mathrm{C}$ measurements of suspended particulate organic matter (SPOM) near Prydz Bay, East Antarctica by Kopczynska et al. (1995) showed that sites with high $\delta^{13} \mathrm{C}$ SPOM values $(-20.1 \%$ o to $-22.4 \%$ ) were characterized by diatoms and large heterotrophic dinoflagellates, whereas the lowest $\delta^{13} \mathrm{C}$ SPOM values $(-29.7 \%$ to $-31.85 \%$ ) were associated with Phaeocystis, naked flagellates and autotrophic dinoflagellates. Wong and Sackett (1978) measured the carbon isotope fractionation of 17 species of marine phytoplankton and showed that Haptophyceae (of which Phaeocystis belongs) had the largest fractionation of $-35.5 \%$.

Therefore, based on the known producers of $\mathrm{C}_{18}$ FAs, observed phytoplankton assemblages within modern surface waters offshore Adélie Land, and the $\delta^{13} \mathrm{C}$ value of $\mathrm{C}_{18}$ FAs in U1357B samples, as discussed above, we argue that the $\mathrm{C}_{18}$ FA here is predominantly produced by Phaeocystis (most likely $P$. antarctica) but with potential minor inputs from other algal species such as Cryptophytes or diatoms.

Phaeocystis antarctica is a major phytoplankton species within the Antarctic, dominating spring phytoplankton blooms, particularly in the Ross Sea (DiTullio et al., 2000; Schoemann et al., 2005). It is known to exist both within sea ice and in open water (Riaux-Gobin et al., 2013) and has been observed in surface waters in great abundance following spring sea-ice break-up, at both coastal and offshore sites in Adélie Land (Riaux-Gobin et al., 2011).

Although a large proportion of organic matter produced in the surface water is recycled in the upper water column, the small fraction which is deposited in the sediment reaches the sea floor through large particles sinking from above as "marine snow". This export production includes large algal cells, fecal pellets, zooplankton carcasses and molts, and amorphous aggregates (Mayer, 1993). In the Ross Sea, aggregates of $P$. antarctica, have been observed to sink at speeds of more than $200 \mathrm{~m} \mathrm{~d}^{-1}$, meaning they could reach deep water very quickly (Asper and Smith, 1999). In this way, a proportion of the lipid content of $P$. antarctica and other algae is transported and sequestered in the sediments.

Initial diagenesis is characterized by the preferential degradation of more labile organic compounds, e.g. sugars, proteins, and amino acids. Proportionally, lipids are relatively recalcitrant compared to other compounds (e.g. amino acids, proteins) and thus are more likely to be preserved as molecular biomarkers on geological timescales, even where 
the rest of the organism may be completely degraded (Peters and Moldowan, 1993). The final proportion of lipids that are preserved within sediments are affected by factors including the export production, $\mathrm{O}_{2}$ content, residence time in the water column and at the sediment-water interface before deposition, molecular reactivity, formation of macromolecular complexes, adsorption to mineral surfaces, and bioturbation (Meyers and Ishiwatari, 1993; Killops and Killops, 2004). Within lacustrine sediments, a significant shift in FA distributions has been shown to occur within 100 years due to early diagenesis, after which the FA distribution remains relatively unaffected by diagenesis (Matsuda, 1978), thus major changes are assumed to reflect primary environmental signals on longer timescales, such as in our Holocene record. Due to the hyperproductivity of the surface waters offshore Adélie land, we assume the dominant inputs of the $\mathrm{C}_{18} \mathrm{FA}$ are from algal sources in overlying waters and up-current regions. Allochthonous inputs, e.g. long-range aeolian transport of plant material, are assumed to be minimal.

\subsubsection{Interpretation of hydrogen isotopes}

Compound-specific $\mathrm{H}$ isotopes of algal biomarkers are a well-used climate proxy in sediments throughout the Cenozoic (e.g. Pagani et al., 2006; Feakins et al., 2012). Although diagenetic alteration, including $\mathrm{H}$-exchange, is possible within sedimentary archives, this has been shown to be minimal in sediments younger than $20 \mathrm{Ma}$ (Sessions et al., 2004). Furthermore, if $\mathrm{H}$-exchange had occurred, we would expect $\delta^{2} \mathrm{H}$ values between different FA chain lengths and closely spaced samples to be driven towards homogeneity, yet large variability remains, suggesting this is not the case. Thus, we are confident that our measured $\mathrm{H}$ isotopes are indicating a primary signal throughout the Holocene.

The $\delta^{2} \mathrm{H}$ value preserved in biomarkers is known to be correlated but offset with the $\delta^{2} \mathrm{H}$ of the water from which the hydrogen was derived. Measured $\delta^{2} \mathrm{H}$ can therefore be described as a function of either the $\delta^{2} \mathrm{H}$ of the water source, or the fractionation occurring between source water and the lipid $\left(\varepsilon_{1 / \mathrm{w}}\right)$ (i.e. vital effects), in which various environmental factors play a part (Sachse et al., 2012).

The main environmental factors controlling $\varepsilon_{1 / \text { w }}$ are salinity and temperature, with which $\delta^{2} \mathrm{H}$ increases by $1 \% 0_{-}-4 \%$ per increase in practical salinity unit (psu) (Schouten et al., 2006; Sachse et al., 2012) and decreases by $2 \%$ - $4 \%$ o per degree $\mathrm{C}$ increase (Zhang et al., 2009), respectively. The $\delta^{2} \mathrm{H}_{\mathrm{FA}}$ record from Site U1357 displays an absolute range of ca. $123 \%$, and millennial- to centennial-scale variability with an amplitude of ca. $50 \%$, throughout the core. This would imply extremely large and pervasive variations in temperature (up to ca. $60^{\circ} \mathrm{C}$ ) and salinity (up to $123 \mathrm{psu}$ ) if fractionation driven by either of these factors were the main control. One study has shown the salinity of present day Adélie shelf waters to vary between 34 and 34.8 psu (Bindoff et al., 2000), while tetraether-lipid based subsurface (50-200 m) temperature estimates from nearby Site MD03-2601 (about $50 \mathrm{~km}$ west of Site U1357) range from -0.17 to $5.35^{\circ} \mathrm{C}$ over the Holocene (Kim et al., 2010). Therefore, fractionation changes driven by temperature or salinity cannot be invoked as a major control on $\delta^{2} \mathrm{H}_{\mathrm{FA}}$ in the Holocene.

Thus, the most parsimonious explanation relates to changes in $\delta^{2} \mathrm{H}_{\mathrm{FA}}$ of the water source (Sachse et al., 2012). In the Adélie Basin, the most apparent controls on this are advection, upwelling, or inputs of isotopically depleted glacial meltwater. The $\delta^{2} \mathrm{H}_{\mathrm{FA}}$ value within Antarctic glaciers is highly depleted relative to sea water due to the Rayleigh distillation process, leading to highly negative isotope values for precipitation over the continent.

The glacial meltwater originating from the Ross Ice Shelf is likely to combine ice precipitated throughout the Holocene and glacial period, and from both the East and West Antarctic Ice Sheets. However, as noted by Shackleton and Kennett (1975) in their first oxygen isotope record of the Cenozoic (see their Fig. 6), most of the ice that melts around the margin has been coastally precipitated (due to higher accumulation rates). Since ice precipitated further inland has a greater residence time (Shackleton and Kennett, 1975) and significantly lower accumulation rates it will contribute significantly less to this signal. Thus, the ice that was melting along this margin is best represented by average values of coastal ice dome records at a similar latitude to that which melted since the LGM (such as TALDICE and Siple Dome) than more southerly locations. Glacial to Holocene $\delta^{2} \mathrm{H}_{\mathrm{FA}}$ values from TALDICE, located on the western edge of the Ross Sea in the East Antarctic, for example, vary between $-276.2 \%$ and $-330.3 \%$ (Steig et al., 1998) (converted from $\delta^{18} \mathrm{O}$ values following the global meteoric water line (GMWL): $\left.\delta^{2} \mathrm{H}_{\mathrm{FA}}=8.13\left(\delta^{18} \mathrm{O}\right)+10.8\right)$, while values from Siple Dome on the eastern edge of the Ross Sea in the West Antarctic vary from ca. $-200 \%$ o to $-293 \%$ o (Brook et al., 2005). Taking the average of these values as a rough estimate for the meltwater gives a $\delta^{2} \mathrm{H}$ value of ca. $-275 \%$. We note our calculations are based on averages of set time periods, which we expect would integrate ice of various ages, rather than extreme values that could relate to specific melt events of ice or biases to certain ages and regions. This seems reasonable, as the isotopic signal of coastal surface waters masses advected from the RIS to the Adélie land (as illustrated in Figs. 3 and 4) must integrate a range of source areas across the RIS and from the coast around to Adélie Land.

In comparison to the highly negative glacial ice isotope composition, sea surface water $\delta^{18} \mathrm{O}$ measurements taken near the Mertz Glacier offshore Adélie Land $\left(140-150^{\circ} \mathrm{E}\right)$ in summer 2000-2001 ranged between $-0.47 \%$ and $0.05 \%$ o (Jacobs et al., 2004), equivalent to $\delta^{2} \mathrm{H}$ values of $6.9 \%$ to $11.2 \%$ (average $=9 \%$ o) following the GMWL. Thus, the two major hydrogen source pools (RIS glacial ice and ocean water) have highly contrasting isotope values, meaning inputs of upstream glacial ice could have a large effect on surface water $\delta^{2} \mathrm{H}$ values in the Adélie Land region. 
Taking the average glacial meltwater $\delta^{2} \mathrm{H}$ value as $-275 \%$ and the average modern Adélie surface water $\delta^{2} \mathrm{H}$ value of $9 \%$ as endmembers, and assuming a biosynthetic offset between the FA and sea water of $173 \%$ o (see below), we can use a simple mixing model to estimate the percentage of glacial meltwater required in the surface waters to change the $\delta^{2} \mathrm{H}_{\mathrm{FA}}$ value to those recorded in U1357B samples. The most negative values occur during the early Holocene, 11.4$8.2 \mathrm{ka}$, averaging $-214.2 \%$ o $(n=18)$ which, converted to a surface water value of $-41 \%$, requires $17.6 \%$ of the surface water to be comprised of glacial meltwater. During this time, we argue that large volumes of meltwater were reaching the core site as local glaciers retreated, leading to intense surface water stratification. Thus, a relatively high percentage of meltwater in the Adélie Land surface waters seems reasonable. During the mid-Holocene (5-4 ka), the average $\delta^{2} \mathrm{H}_{\mathrm{FA}}$ is very similar $(-213.9 \%, n=7)$, requiring $17.2 \%$ of the surface water to be derived from glacial meltwater. During this time, we argue for the dominant meltwater source as coming from the Ross Sea and interpret this as a major period of glacial retreat (see Sect. 5.2), during which large volumes of meltwater are injected into the surface water and transported to the Adélie coast. In contrast, the most recent samples (last $0.5 \mathrm{ka}, n=7$ ), which includes the most positive value of the record, has an average $\delta^{2} \mathrm{H}_{\mathrm{FA}}$ value of $-174.5 \%$. This brings the surface water value up to $-1.5 \%$, which approaches modern measured values, and requires just $3.7 \%$ (e.g. well within uncertainties) of the surface waters in the Adélie Land to be glacial meltwater. However, it is also possible that the meltwater was dominated by more LGMaged ice. In either case, perturbation of the exact isotopic values still indicate only significant changes in the flux of glacial meltwater can account for this signal. For example, the use of $-330 \%$ (LGM values) for the ice input gives an estimate of $3 \%$ of the surface water being comprised of glacial meltwater for latest Holocene values, and $14.7 \%$ for values prior to $8 \mathrm{ka}$. Taking $-240 \%$ (Holocene values) for the ice input gives an estimate of $4 \%$ for latest Holocene values, and $20 \%$ for values prior to $8 \mathrm{ka}$ ). Thus even with changing isotopic values though the deglacial, this signal of changing meltwater flux would still dominate. We note these are semi-quantitative estimates, as the salinity and temperature fractionation could reduce these estimates further (but cannot account for the whole signal).

Surface water $\delta^{18} \mathrm{O}$ values around Antarctica (below $60^{\circ} \mathrm{S}$ ), measured between 1964 and 2006, ranged from $-8.52 \%$ o to $0.42 \%$ o (Schmidt et al., 1999), the most negative value having been measured proximal to the George VI Ice Shelf edge, where high melt rates have been observed (Potter and Paren, 1985). If converted to $\delta^{2} \mathrm{H}$ using the global meteoric water line, these values give a $\delta^{2} \mathrm{H}$ range of $83.4 \%$. Thus, our absolute $\delta^{2} \mathrm{H}_{\mathrm{FA}}$ range of $123 \%$ over the Holocene suggests a range of isotopically depleted meltwater inputs to our core site over this time that are 1.5 times greater than that occurring in different locations around the Antarctic in recent decades. This seems plausible based on geological evidence that indicates large glacial retreat and ice mass loss occurred from the Ross Sea sector during the Holocene (Anderson et al., 2014; McKay et al., 2016; Spector et al., 2017), meaning resultant changes in surface water are likely to be greater in magnitude than observed around the Antarctic in recent decades. This assumes a relatively constant value for the isotopic composition of glacial meltwater, however, there is likely to be some variability due to the possibility of melting ice of different $\delta^{2} \mathrm{H}$ values. But, as discussed above, the meltwater is best represented by the average values of the ice sheet, rather than extreme values, since it must (over the broad expanse of the RIS) include an integrated signal, and thus the actual variation in meltwater $\delta^{2} \mathrm{H}$ will be significantly within the range of the endmembers.

Although the biosynthetic fractionation of the $\mathrm{C}_{18}$ FAs in U1357B is unknown, we assume that the offset with surface water remains relatively constant throughout the record. Sessions et al. (1999) showed the biosynthetic fractionation of hydrogen isotopes in the $\mathrm{C}_{18}$ FA from four different marine algae to range from $-189 \%$ o to $-157 \%$. If we take the average of these values of $173 \%$ and apply this as a biosynthetic offset to the youngest samples in U1357B (last $0.5 \mathrm{ka}$, $n=7$ ), which includes the most positive value of the record, gives an average $\delta^{2} \mathrm{H}_{\mathrm{FA}}$ value of $-174.5 \%$. This brings the surface water value up to $-1.5 \%$, which approaches modern measured values (Jacobs et al., 2004).

Furthermore, it is interesting to note that the biosynthetic offsets measured by Sessions et al. (1999) for the $\mathrm{C}_{18} \mathrm{FA}$ from different algal species have a total $\delta^{2} \mathrm{H}$ range of $32 \%$. Although we cannot dismiss changes in the relative contribution of $\mathrm{C}_{18}$ from different species in U1357B samples (and thus different biosynthetic fractionations), we argue this would only be a minor control on $\delta^{2} \mathrm{H}$ compared to other influences. As a thought experiment, taking the above endmembers for biosynthetic fractionation from Sessions et al. (1999), even with a $100 \%$ change in $C_{18}$ producer to a different algal source, this could only explain a quarter of the observed $\delta^{2} \mathrm{H}$ change (i.e. $32 \%$ of $123 \%$ ).

Therefore, we interpret the first-order control on $\delta^{2} \mathrm{H}_{\mathrm{FA}}$ at Site U1357 as inputs of isotopically depleted glacial meltwater. Such inputs are, in turn, influenced by the mass balance of the proximal or up-current glaciers and ice shelves.

\subsection{Other proxies}

Grain size, natural gamma radiation (NGR) and terrigenous and biosiliceous mass accumulation rates (MARs) reflect changing sediment delivery either driven via local glacial meltwater discharge or advection of suspended sediment by oceanic currents. The diene/triene HBI ratio is used as a proxy for coastal sea-ice presence (Massé et al., 2011), in which high values indicate greater sea-ice extent over the core site. The HBI diene, also known as Ice Proxy for the Southern Ocean with 25 carbon atoms (IPSO25), has been 
shown to derive from a sea-ice-associated diatom (Belt et al., 2016), whereas the HBI triene is produced in the marginal ice zone (Smik et al., 2016). Ba/Ti enrichment is considered to reflect enhanced primary productivity. Interpretation of these proxies is discussed in more detail in Sect. S2.

\section{Results}

\subsection{Model simulations}

We employed a series of sensitivity tests from a highresolution numerical ocean model by releasing a range of meltwater volumes ( 0.01 to $1 \mathrm{~Sv}$ ) from along the front of the Ross Ice Shelf (RIS) to determine its pathway. This demonstrates that, even under the lowest flux scenarios, freshwater is transported anticlockwise, entrained within the coastal current (Figs. 2 and 3), and reaches Site U1357 within a year. Moreover, although the higher-input scenarios are not realistic values for the release of meltwater since the LGM, the full range of simulations show a strong linear relationship between meltwater flux and salinity change at the core site (Fig. 3), suggesting the magnitude of the signal recorded at Site U1357 is directly related to the magnitude of meltwater released. Thus, we argue that any changes in Ross Sea water mass properties (salinity and temperature) would have a direct influence on surface water mass properties at Site U1357 during the Holocene.

\subsection{Geochemical data}

The main datasets from Core U1357 are displayed in Figs. 2 and S2. FA $\delta^{2} \mathrm{H}$ (Fig. 4a) shows and overall trend towards more positive values over the course of the Holocene, indicating a decline in glacial meltwater input. There is a notable deviation from this trend in the mid-Holocene involving a sustained period of more negative $\delta^{2} \mathrm{H}$ values, suggesting a peak in meltwater input, centred on ca. $4.4 \mathrm{ka}$. This midHolocene deviation in FA $\delta^{2} \mathrm{H}$ coincides with an increase in the HBI diene/triene ratio (Fig. 4c), indicating a baseline shift in sea-ice conditions whereby greater sea-ice concentrations are sustained for the rest of the Holocene. This is a similar pattern to the relative abundance of the Fragilariopsis curta group (Fig. 4b), a sea-ice diatom group in core MD03-2601 that also indicates a shift in sea-ice concentrations. Along the entire record, $\mathrm{Ba} / \mathrm{Ti}$ ratios show persistent periodic fluctuations in marine productivity, with values between 0.1 and 2.7 (Fig. 4g). A marked enrichment can be observed at ca. $4.4 \mathrm{ka}$ reaching $\mathrm{Ba} / \mathrm{Ti}$ ratio values over 36.1 , suggesting a peak in primary productivity, before declining to background levels again (Fig. 4g).

\subsection{Sedimentological data}

The stratigraphy of U1357B is divided into three units: the lowermost $10 \mathrm{~cm}$ recovered Last Glacial Maximum (LGM)
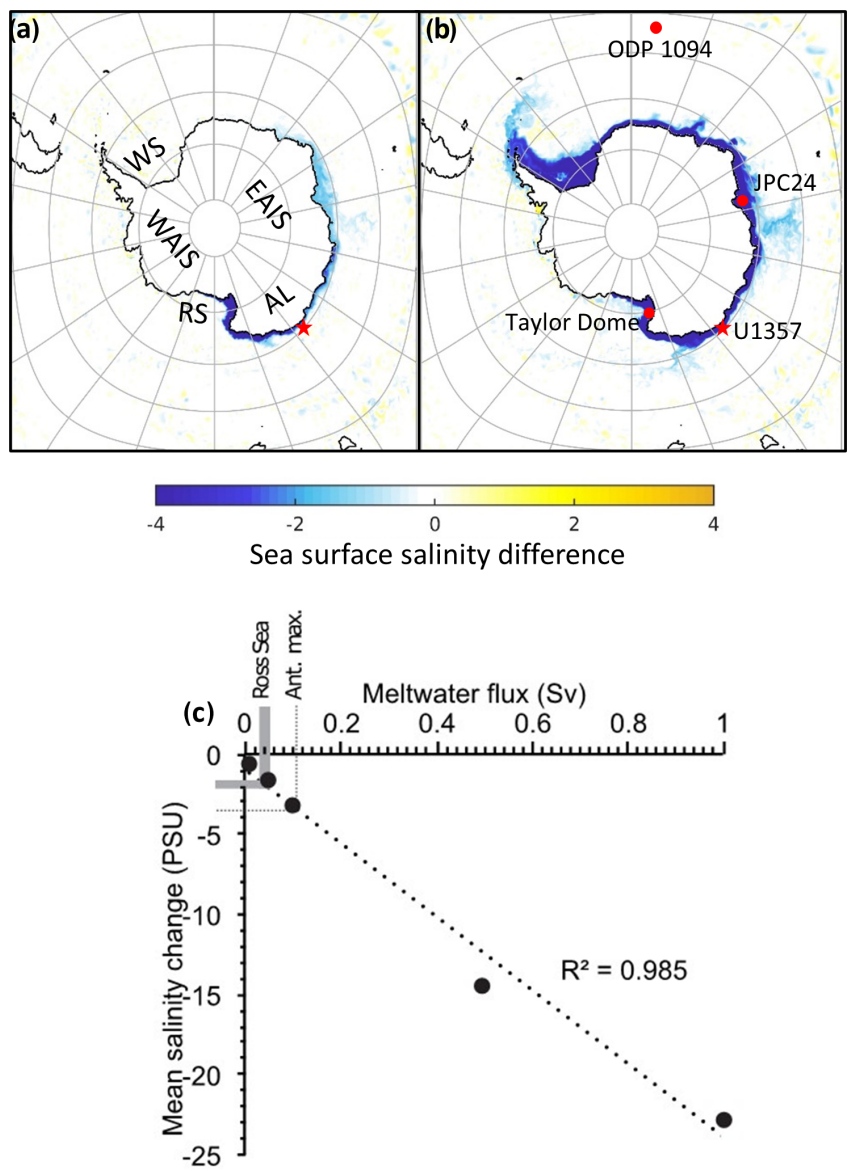

Figure 2. MITgcm simulations of meltwater release from along the edge of the Ross Ice Shelf. The top two images show sea surface salinity difference (in practical salinity units) after 3.5 model years resulting from meltwater release volumes of (a) $0.1 \mathrm{~Sv}(2 \times$ $10^{13} \mathrm{~m}^{3}$ total ice volume equivalent) and (b) $0.5 \mathrm{~Sv}\left(1 \times 10^{14} \mathrm{~m}^{3}\right.$ total ice volume equivalent). The red star indicates the position of Site U1357 (this study), and red dots show positions of other core sites mentioned in this study where a mid-Holocene increase in sea ice and/or cooling is recorded: Taylor Dome (Steig et al., 1998; Baggenstos et al., 2018), JPC24 (Denis et al., 2010) and ODP 1094 (Nielsen et al., 2007). AL stands for Adélie Land, RS stands for Ross Sea, WS stands for Weddell Sea, EAIS stands for East Antarctic Ice Sheet, and WAIS stands for West Antarctic Ice Sheet. (c) Scatterplot of simulated meltwater flux (Sv) against mean salinity difference at U1357 core site. The grey band indicates the range of plausible Holocene to deglacial Ross Sea meltwater inputs. The dotted line indicates maximum Antarctic meltwater during the Holocene.

till (Unit III), overlain by $15 \mathrm{~m}$ of laminated mud-rich diatom oozes with ice-rafted debris (IRD) (Unit II), and the uppermost $171 \mathrm{~m}$ (Unit I) consists of laminated diatom ooze with a general lack of IRD and a significant reduction in terrigenous sediment (Escutia et al., 2011).

Between ca. 11.4 and $8 \mathrm{ka}$, U1357B has a relatively high terrigenous component (i.e. high Natural Gamma Radiation 


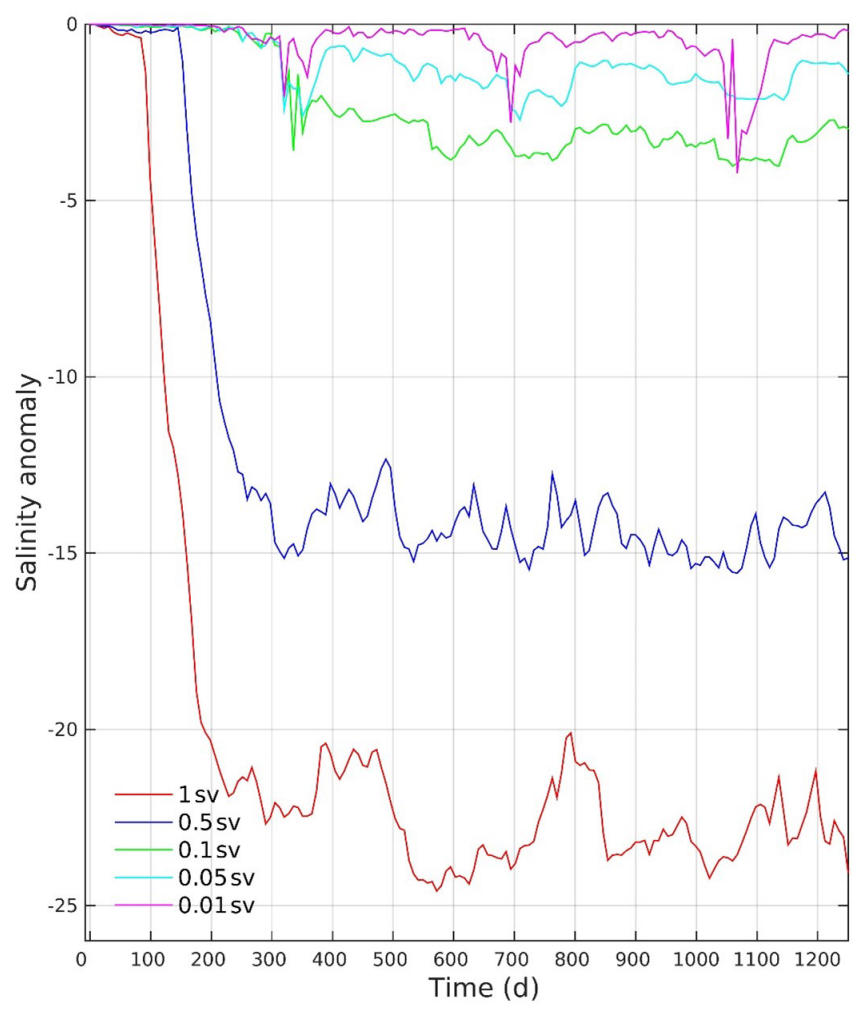

Figure 3. Simulated salinity anomalies over time at Site U1357 for the five meltwater release experiments.

(NGR) content and low BSi \%; Fig. S4). The grain size distribution contains coarse tails of fine $(125-250 \mu \mathrm{m})$ to medium sands $(250-500 \mu \mathrm{m})$, but only one sample contains coarse sands $(>500 \mu \mathrm{m})$ that may represent iceberg-rafted debris (IBRD). However, terrigenous content and IBRD is more common in the underlying Unit II. The fine-grained sands and muds have a distribution with similar modes to overlying intervals, albeit with an increase in the size of the coarse silt and very fine sand modes. There is a subtle increase in sorting up core between ca. 11.4 and ca. $8 \mathrm{ka}$ (from very poorly to poorly sorted, Fig. 5c).

Between 9 and $4.5 \mathrm{ka}$, mass accumulation rates (MARs) (both biogenic and terrigenous; Fig. 5e) are relatively high, albeit with millennial scale variability. However, the mean grain size and sorting of the terrigenous material is relatively stable throughout the entire interval, and as with the rest of Unit I there is an almost complete lack of IBRD. There is a rapid increase in mud content at $4.5 \mathrm{ka}$ coincident with a reduction in both the biogenic and terrigenous MARs, although the terrigenous MAR curve shows higher accumulation rates than the biogenic MAR curve (Fig. 5e and f).

\section{Discussion}

The sedimentology and geometry of the drift prior to $\sim 11.4 \mathrm{ka}$ (Unit II) is consistent with the calving bay re- entrant model (Domack et al., 2006; Leventer et al., 2006) (Figs. 1 and S4; Supplement), whereby LGM ice retreated in the deeper troughs while remaining grounded on shallower banks and ridges. Sediment-laden meltwater and IRD content in Unit II ( $>11.4 \mathrm{ka}$ ) is thus likely derived from local outlet glaciers. However, anomalously old radiocarbon ages due to glacial reworking precludes development of a reliable age model prior to the Holocene (Supplement).

The results of model simulations (Sect. 5.1) indicate that, although several small glaciers within Adélie Land may contribute meltwater to the site, the region is also likely to be influenced significantly by changes in Ross Sea waters. Freshwater release simulations from the Ross Ice Shelf (RIS) confirm this oceanographic continuity between the Ross Sea and the Wilkes region (Fig. 2). All five simulations indicate that meltwater released from the edge of the RIS is almost completely entrained within the westward coastal surface current and reaches Site U1357 within 4 months to 1 year (Fig. 3). These fluxes cover a wide range of meltwater inputs and show a strong linear relationship with salinity at the core site (Fig. 4a). This suggests that the magnitude of the signal recorded at Site U1357 is directly related to the magnitude of the meltwater input.

Local processes also play a critical role in this region. For example, episodic calving events of the Mertz Glacier tongue release fast ice over the drill site and create strong surface water stratification, cutting off local AABW production (Campagne et al., 2015). Although appearing to be only a local process, there is still a regional (Ross Sea) influence, as this fast ice that builds up behind the Mertz Glacier is formed by the freezing of fresher AASW transported from the Ross Sea (Fig. 2). Thus, conditions in the Ross Sea, such as the melting of isotopically depleted glacial ice, would influence both the isotopic composition and amount of this sea ice.

\subsection{Early Holocene}

The base of the drift deposit shows downlapping of material, suggesting a supply from the south, indicating local focusing of meltwater and terrigenous material was the dominating influence until $11.4 \mathrm{ka}$ (Sect. S2.2 and Fig. S4). This is overlain by onlapping strata (Unit I) with the drift forming an east-west elongation on the northern flank of the Dumont d'Urville Trough, which is more consistent with advection of material from the east than with delivery from local outlet glaciers to the south. Thus, an increased meltwater influence from the Ross Sea is likely since this time.

Due to the potential for competing sources of glacial meltwater in the earliest Holocene, we focus our study on Unit $\mathrm{I}$, where there is less influence of calving bay processes (Escutia et al., 2011). However, the earliest part of Unit I (11.4 to $8 \mathrm{ka}$ ), which includes the most negative $\delta^{2} \mathrm{H}_{\mathrm{FA}}$ values, is characterized by a very gradual up-core increase of sorting in the terrigenous sediment supply, decreasing natural gamma ray (NGR) values (Fig. 5b and c), and a general lack of IRD 


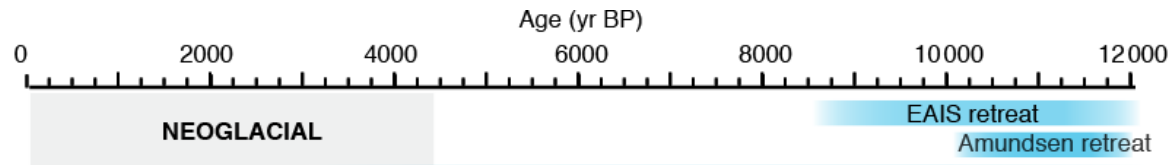

(a)

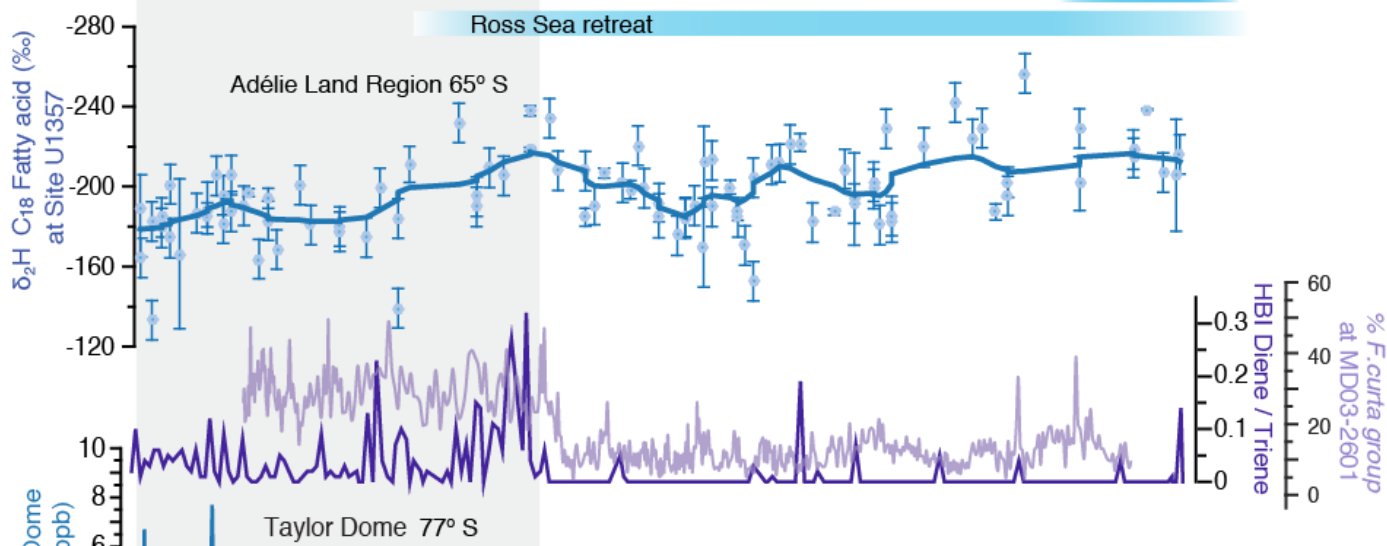

(d)

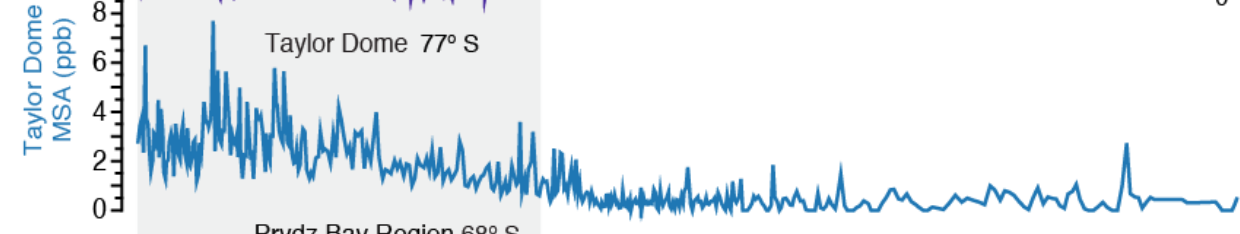

(e) Prydz Bay Region $68^{\circ} \mathrm{S}$

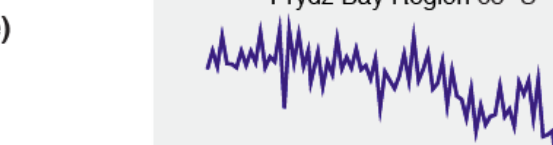

(f)
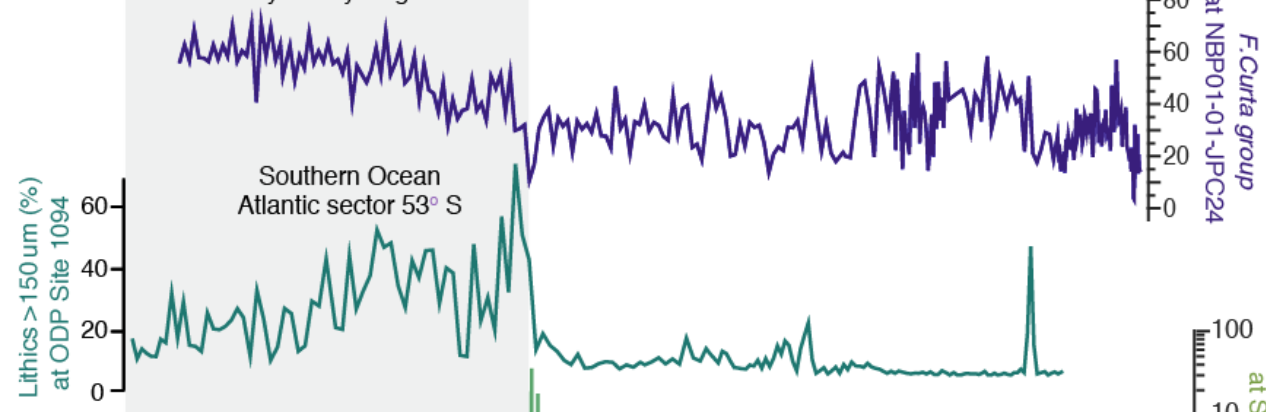

(g)

(h)

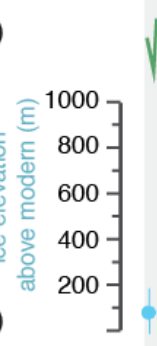
Adélie Land Region $65^{\circ} \mathrm{S}$

(i)

Figure 4. Holocene Adélie Land proxy records from IODP Site U1357 and other circum-Antarctic sites. Glacial retreat chronologies are shown as bars at the top, as discussed in the text. (a) $\delta^{2} \mathrm{H} \mathrm{C}_{18}$ fatty acid at Site U1357 (errors bars based on replicates), with robust locally weighted smoothing (rlowss). (b) Fragilariopsis curta group (F. curta and F. cylindrus) relative abundance at MD03-2601, as a proxy of seaice conditions (Crosta et al., 2008). (c) Di-unsaturated HBI ( $\mathrm{C}_{25: 2}$; Diene)/tri-unsaturated HBI isomer $\left(\mathrm{C}_{25: 3}\right.$; Triene) ratio at Site U1357. (d) Methanesulfonate (MSA) concentrations (ppb) from Taylor Dome ice core. (e) F. curta group relative abundances in core NBP-01JPC24. (f) Coarse lithic (ice-rafted) content at TTN057-13-PC4 (Hodell et al., 2001). (g) Ba/Ti (logarithmic scale) at Site U1357. (h) ${ }^{10}$ Be cosmogenic nuclide ages from Scott Glacier in the southwestern Ross Ice Shelf region (Spector et al., 2017). (i) Temperature signal from principal component analyses of five $\delta^{18} \mathrm{O}$ records in five East Antarctic ice cores (Vostok, EPICA Dome C, EPICA Dronning Maud Land, Dome Fuji, and Talos Dome) (Masson-Delmotte et al., 2011). 


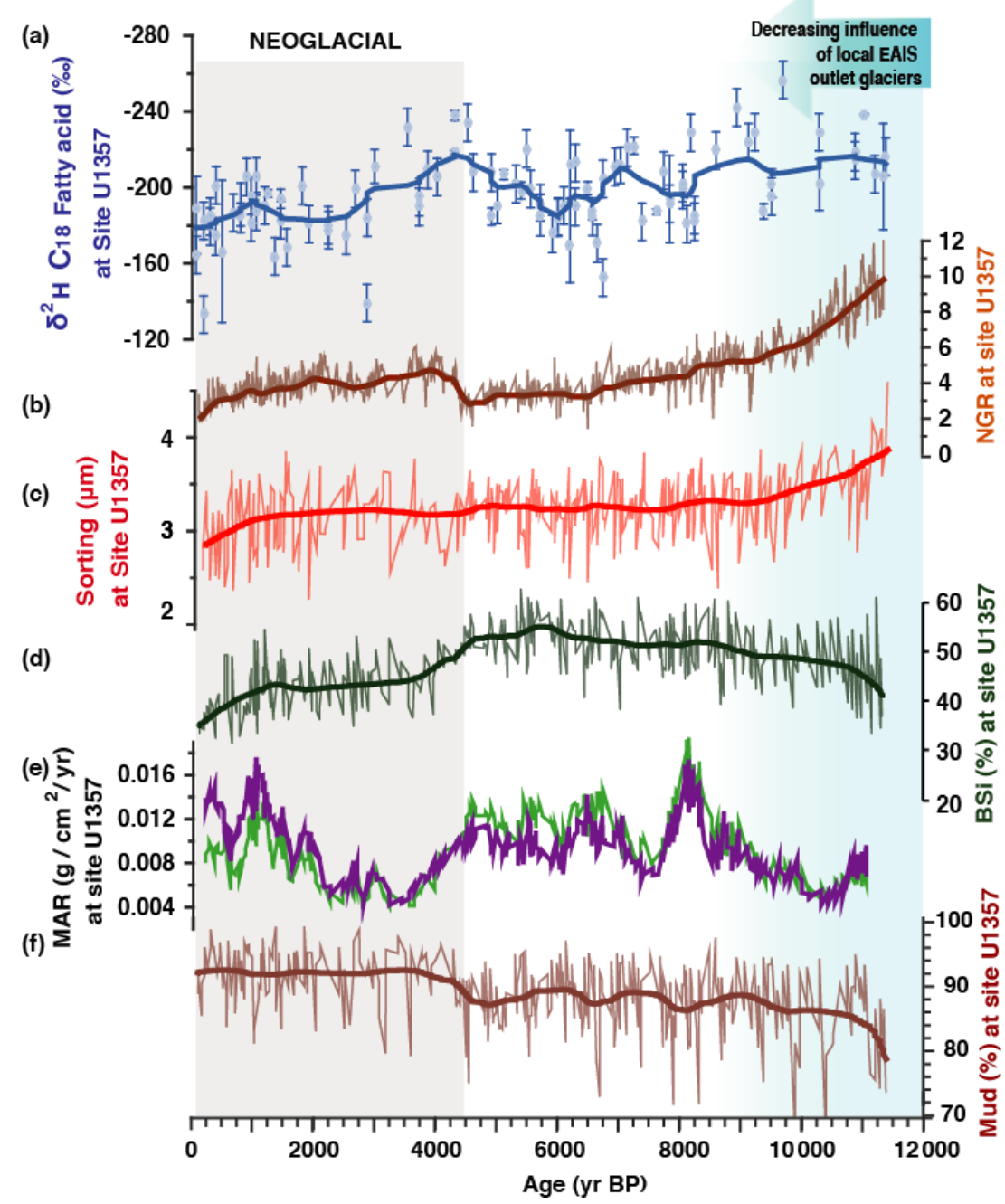

Figure 5. Holocene Adélie Land proxy records from IODP Site U1357 (a) $\mathrm{C}_{18}$ fatty acid $\delta^{2} \mathrm{H}$ (errors bars based on replicate analyses); the heavy line is a robust locally weighted scatterplot smoothing (rlowss). (b) Natural Gamma Radiation; the heavy line is a rlowss .(c) Grain sorting $(\mu \mathrm{m})$ calculated following Folk and Ward (1957); the heavy line is a rlowss. (d) Percentage of biogenic silica (BSi); the heavy line is a rlowss. (e) Mass accumulation rates of biogenic (green line) and terrigenous (purple line) material (f) Percentage of mud; the heavy line is a rlowss.

(Escutia et al., 2011). We conservatively interpret this as potentially maintaining some local glacial meltwater input from local outlet glaciers in the lowermost interval of Unit I. Nevertheless, this process was probably greatly reduced relative to Unit II deposition and it is likely much of this signal between 11.4 and 8 ka could still be derived from water masses advecting to the site from the east (e.g. the Ross Sea).

This is supported by geological and cosmogenic evidence which demonstrates that the majority of the margin of the East Antarctic, and also the Amundsen Sea margins, had retreated to their modern-day positions by $\sim 10 \mathrm{ka}$ (Bentley et al., 2014; Mackintosh et al., 2014; Hillenbrand et al., 2017). Thus, these margins are unlikely to contribute large scale shifts in meltwater fluxes to the Adélie Coast during most of the Holocene. The history of grounding line retreat in the Ross sea is relatively well-constrained, particularly in the western Ross Sea, and the loss of residual ice caps appears to be largely complete by ca. $7 \mathrm{ka}$ to the immediate north of Ross Island, near the present-day calving line front of the Ross Ice Shelf (Anderson et al., 2014; McKay et al., 2016). Indeed, the phase of isotopically depleted glacial meltwater is apparent at Site U1357 between 8 and 7 ka could be sourced from the Ross Sea, reconciling our data with these chronologies. Prior to $8 \mathrm{ka}$, any meltwater signal in U1357B is potentially influenced by local glacier retreat, based on the caveats noted earlier in the grain size and geophysical datasets (Sect. S2.2), although we note a dominant Ross Sea contribution to this signal is possible.

Glacial retreat, however, persisted in the Ross Sea until at least $3 \mathrm{ka}$ (Anderson et al., 2014; Spector et al., 2017) pro- 
viding a large upstream source of meltwater feeding into the Adélie Coast. We therefore interpret our meltwater signal as being dominated by Ross Sea inputs since at least $8 \mathrm{ka}$, but potentially as early as $11.4 \mathrm{ka}$. Furthermore, the retreat of grounded ice from the outer Ross Sea continental shelf was accompanied by the growth of a significant floating ice shelf (which was not the case in the Amundsen Sea or proximal East Antarctic coast) (Bentley et al., 2014).

An overall trend to more positive $\delta^{2} \mathrm{H}_{\mathrm{FA}}$ values, from the most negative value of the record at $\sim 9.6 \mathrm{ka}$, to $\sim 8 \mathrm{ka}$ indicates decreasing meltwater (Fig. 4a), thus suggesting a gradually diminished input from either local outlet glaciers or the Ross Sea. This is associated with an increase in MARs, between 10 and $8 \mathrm{ka}$, and is tentatively interpreted to represent the final retreat of residual ice from local bathymetric highs allowing more material to advect into the drift (Fig. 5e). Although there is millennial-scale variability, MARs remain relatively high until $4.5 \mathrm{ka}$. However, $\delta^{2} \mathrm{H}_{\mathrm{FA}}$ and MARs show greater coherence at the millennial-scale after $7 \mathrm{ka}$, suggesting that increased fluxes of glacial meltwater broadly corresponded to stronger easterly currents, which advected biogenic and terrigenous material into the drift.

\subsection{Middle Holocene}

A negative excursion in $\delta^{2} \mathrm{H}_{\mathrm{FA}}$ starting from $6 \mathrm{ka}$ and culminating at $4.5 \mathrm{ka}$ is interpreted to record a period of enhanced glacial meltwater flux to the site relating to a final retreat phase of the major ice sheet grounding line in the Ross Sea embayment (Fig. 6). A marked enrichment of $\mathrm{Ba} / \mathrm{Ti}$ ratios also occurs at $4.5 \mathrm{ka}$, reaching values of 36.1 , on a background of baseline fluctuations between 0.1 and 2.7 (Fig. 2g), which suggests enhanced primary productivity, potentially driven by meltwater-induced stratification. Ongoing Holocene retreat in the Ross Sea is interpreted to be primarily the consequence of marine ice sheet instability processes resulting from the overdeepened continental shelf in that sector (McKay et al., 2016). We use the model presented by Lowry et al. (2019) to help constrain the pattern and rate of retreat of the grounding line to the south of Ross Island. This model compares geological data with ice sheet model experiments that were forced by a range of environmental conditions. These experiments indicate that the Ross Ice shelf cavity only started to expand once the grounding line retreated to the south of Ross Island. Furthermore, to reconcile these model experiments with geological datasets, the cavity expansion was not completed until the mid-Holocene (ca. $5 \mathrm{ka}$ ). This reconciles well with ${ }^{10} \mathrm{Be}$ exposure ages of erratics in coastal nunataks at the confluence of the Mercer Ice Stream, and Reedy Glacier indicate $105 \mathrm{~m}$ of ice sheet deflation since $6.8 \mathrm{ka}$, with $40 \mathrm{~m}$ of this after $4.9 \mathrm{ka}$ (Todd et al., 2010), indicating the most rapid phase of retreat occurred between 6.8 and $4.9 \mathrm{ka}$. More recent deflation profiles for the Beardmore Glacier $\left(84^{\circ} \mathrm{S}\right)$ and Scott Glacier $\left(86^{\circ} \mathrm{S}\right)$ regions show sustained thinning between ca. 9 and $8 \mathrm{ka}$, but Scott
Glacier experiences a second phase of rapid thinning of ca. $200 \mathrm{~m}$ between 6.8 and $5.3 \mathrm{ka}$ (Fig. 2h), followed by a slower rate of thinning of between 5.3 and $3.5 \mathrm{ka}$ of ca. $100 \mathrm{~m}$. Ages younger than this, near the modern surface, are thought to be related to surface ablation rather than dynamic thinning. This suggests that the grounding line was at its modern location by ca. $3.5 \mathrm{ka}$ (Spector et al., 2017), although it may have potentially retreated further south, followed by a short duration readvance of the grounding line (Kingslake, et al., 2018). Glaciological evidence from radar profiles suggests the development of divide flow on Roosevelt Island occurred sometime between 3 and $4 \mathrm{ka}$, suggesting that the ice sheet thickness was at least $500 \mathrm{~m}$ thicker until this time (Conway et al., 1999). Combined, these lines of evidence suggest the majority of grounding line retreat south of Ross Island occurred after $8 \mathrm{ka}$, with a sustained retreat occurring after $6.8 \mathrm{ka}$, consistent with the timing of the largest inputs of glacial meltwater feeding the U1357 site. However, a younger age (e.g. 3$3.5 \mathrm{ka}$ ) for final establishment of the modern grounding line position is consistent with our interpretation, as although the meltwater signal in $\delta^{2} \mathrm{H}_{\mathrm{FA}}$ peaks at $4.5 \mathrm{ka}$, it does not stabilize at lower levels until $3 \mathrm{ka}$.

The $\delta^{2} \mathrm{H}_{\mathrm{FA}}$ peak at $4.5 \mathrm{ka}$ in $\mathrm{U} 1357$ coincides directly with a rapid shift in HBI biomarker ratios at the site (Fig. 4a and c), as well as sea-ice proxies recorded in nearby site MD032601 (Fig. 4b), in the Ross embayment (Taylor Dome ice core on a revised age model) (Steig et al., 1998; Baggenstos et al., 2018) (Fig. 4d) and other sectors of the East Antarctic margin in Prydz Bay (JPC24) (Denis et al., 2010) (Fig. 4e), reflecting a widespread increase in coastal sea-ice concentration and duration. We interpret decreasing MAR and finergrained terrigenous content (e.g. increased mud percent) at Site U1357 after $4.5 \mathrm{ka}$ (Fig. 5e and f) to also be a consequence of increased coastal sea ice, reducing wind stress on the ocean surface and limiting the easterly advection of detritus to the drift deposit.

Coastal sea-ice concentration and duration remain high throughout the rest of the Holocene as recorded by our HBI data (Fig. 4c), sea-ice diatoms in core MD03-2601 (Crosta et al., 2008), methanesulfonic acid concentration in Taylor dome ice core(Steig et al., 1998), and sea-ice diatoms in core JPC24 (Denis et al., 2010), compared to the period before $4.5 \mathrm{ka}$, despite a decrease in glacial meltwater flux to the U1357 site. In addition, meltwater input prior to $4.5 \mathrm{ka}$ does not have a major influence on sea-ice extent. Thus, an increase in meltwater flux cannot explain the Neoglacial intensification of sea ice at $\sim 4.5 \mathrm{ka}$. Here, we propose that greater coastal sea-ice cover since $4.5 \mathrm{ka}$ is related to the development of a large ice shelf cavity in the Ross Sea as the ice sheet retreats (Fig. 6), which pervasively modified ice shelfocean interactions and increased sea-ice production. Models suggest a large cavity on the continental shelf increases contact between basal-ice and circulating ocean water, driving the formation of a cool, freshwater mass feeding into the AASW, stabilizing the water column and enhancing the pro- 

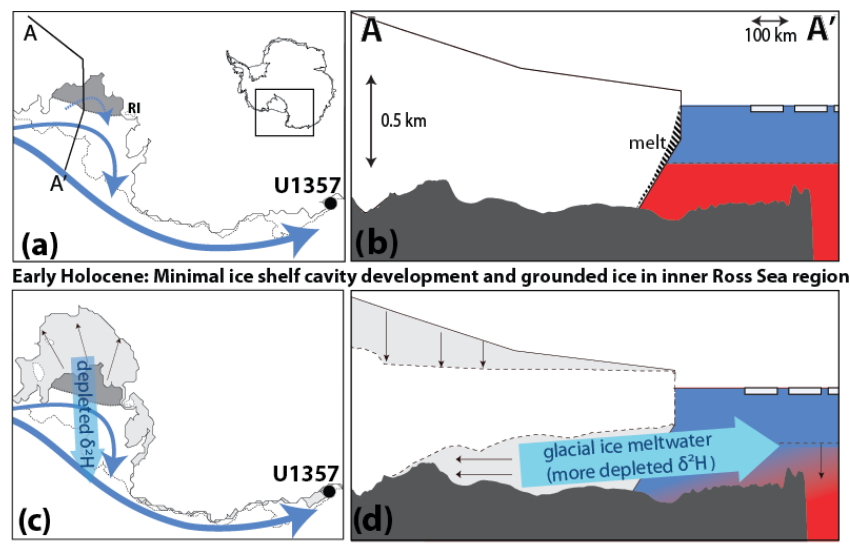

Mid-Holocene: Transient Ross Sea retreat event(s) and establishment of Ross Ice Shelf cavity

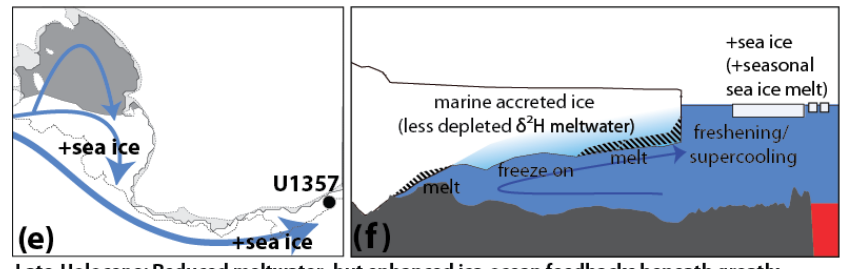

Late Holocene: Reduced meltwater, but enhanced ice-ocean feedbacks beneath greatly

expanded Ross Ice Shelf cavity

Figure 6. Conceptual model of evolving Holocene glacial and oceanographic conditions in the Ross Sea region. Panels on the left show modelled grounding line positions (McKay et al., 2016) and proposed circulation of surface and sub-ice shelf circulating waters (light blue arrows). Panels on the right show cross sections of the Ross Ice Shelf (RIS) and ice-ocean interactions. Dark blue indicates cool surface waters, and red indicates warm subsurface waters. (a) The grounding line in Adélie Land is near its modern location, but near Ross Island (RI) in the Ross Sea and the ice shelf cavity (dark grey shading) it is reduced in size relative to today (McKay et al., 2016). (b) Continental shelf profile A-A' (a) shows a Ross Sea grounding line in a mid-continental shelf location in close proximity to the RIS calving line (McKay et al., 2016), with subsurface warming on the continental shelf triggering WAIS deglaciation (Hillenbrand et al., 2017). (c) Most grounding line retreat south of RI occurred between 9 and $4.5 \mathrm{ka}$ (light grey shading with black arrows represents area of retreat over this period), proposed to be the consequence of marine ice sheet instability, but the ice shelf calving line remained near its present position (McKay et al., 2016; Spector et al., 2017). (d) Grounding line retreat and ice shelf thinning released meltwater with negative $\delta^{2} \mathrm{H}$ into the surface waters. Increasing ice shelf-oceanic interactions with the development of the ice shelf cavity (dark grey) led to enhanced Antarctic Surface Water formation; (f) Minimal grounding line retreat has occurred since $4.5 \mathrm{ka}$, and the RIS super-cools AASW, leading to enhanced sea-ice formation despite reduced glacial meltwater flux. Seasonal sea-ice meltwater further freshens and cools AASW. Increased production of AASW on the continental shelf leads to isopycnal deepening (dotted line) and limits flow onto the continental shelf, slowing further grounding line retreat. However, as the ice shelf is near steady-state mass balance and there is a component of marine accreted ice at the base of the ice shelf (Rignot et al., 2013), the strength of the $\delta^{2} \mathrm{H}$ signal is reduced relative to periods of mass balance loss. duction of sea ice (Hellmer, 2004) (Fig. 6). However, under small cavities such as in the modern Amundsen Sea influenced by warm-water incursions, ice shelf melting results in an "ice pump" enhancement of sub-ice shelf circulation. This increases flow of warm Circumpolar Deep Water (CDW) under the ice shelf that is 100-500 times the rate of melt, and this volume of water does not allow for supercooling. Small cavity ice shelf outflows are therefore warm and act to restrict sea ice at the ice shelf front (Jourdain et al., 2017). Thus, during the Holocene, the size of the cavity must have reached a threshold after which this positive warming feedback switched to a negative feedback. We argue that such a tipping point takes place at $4.5 \mathrm{ka}$, when our proxy data suggest meltwater peaks, and would explain why the increase in sea-ice concentration appears rapid and only occurs at the peak of the meltwater input and not during its prior increase or previous meltwater inputs (Fig. $4 \mathrm{a}-\mathrm{g}$ ).

Although the glacial meltwater volume is greatly reduced after $4.5 \mathrm{ka}$, the volume of Ice Shelf Water (ISW) produced beneath the modern RIS is estimated at 0.86-1.6 Sv (Holland et al., 2003; Smethie and Jacobs, 2005). We note that ISW is not glacial meltwater, but it is defined as a supercooled water mass formed through interaction with the base of the RIS but once formed acts to modify other water masses in the Ross Sea. A significant proportion of ISW is high salinity and is thus advected northwards at intermediate waters depth to ultimately form AABW. However, a significant volume of ISW is lower salinity and buoyant, due to development of frazil ice, and acts to mixes with surface waters (Robinson et al., 2014). Currently, a 0.4 Sv plume of ISW in the western margin of the Ross Ice Shelf (Robinson et al., 2014) is directly delivered to the surface resulting in enhanced sea-ice production, while seasonal melt of this enhanced sea ice further acts to cool and freshen surface waters. Although unrealistic in the context of a post-LGM meltwater flux from the Ross Sea alone, the larger meltwater release scenarios in our simulations ( 0.5 to $1 \mathrm{~Sv}$ ) show the potential pathways that a cool, fresher surface water mass collecting and forming on the broad Ross Sea continental shelf would follow (Fig. 2b). These waters are transported in easterly coastal currents to the Weddell Sea and the Antarctic Peninsula. This eventually retroflects to join the Antarctic Circumpolar Current (Fig. 2b) and thus has potential for cooling and freshening in the South Atlantic far offshore, as the ice shelf cavity increased in the Ross Sea. Indeed, offshore site ODP 1094 records increased lithics in the South Atlantic after $4.5 \mathrm{ka}$ (Fig. 4f), relative to the period before, suggested to have been predominantly transported by sea ice indicating a cooling in sea surface temperatures and increase in sea-ice extent in the South Atlantic at this time (Hodell et al., 2001; Nielsen et al., 2007). However, it also is feasible that this circum-Antarctic cooling signal indicates similar melt processes may have been occurring in the Weddell Sea at $\sim 4.5 \mathrm{ka}$, as suggested by cosmogenic nuclide data (Hein et al., 2016). 


\subsection{What Drove the Neoglacial Transition?}

Our observed coastal sea-ice increase is part of a widespread transition to Neoglacial conditions both globally and at high southern latitudes (Kim et al., 2002; Masson-Delmotte et al., 2011; Marcott et al., 2013; Solomina et al., 2015). However, most current climate models do not simulate this cooling trend, resulting in a significant data-model mismatch (Liu et al., 2014) (Fig. 7). Marine ice sheet retreat along the Pacific margin of West Antarctica has previously been proposed to be triggered by enhanced wind-driven incursions of warm CDW onto the continental shelves in the early Holocene (Hillenbrand et al., 2017), with continued retreat in the Ross Sea being the consequence of the overdeepened continental shelf and marine ice sheet instability processes (McKay et al., 2016). We propose that a series of negative feedbacks was also associated with the latter phases of this retreat due to the RIS cavity expansion that occurred in the mid-Holocene, with similar processes possibly occurring in the Weddell Sea, leading to the onset and continuation of Neoglacial conditions. Widespread albedo changes associated with increased coastal sea ice would have amplified regional cooling trends (Masson-Delmotte et al., 2011), whilst increased stratification resulting from seasonal sea-ice melt and increased ISW production drove the deepening of the fresher water surface isopycnal at the continental shelf break. Grounding line retreat creates new space for continental shelf water masses to form, while ice shelf cavity expansion promotes supercooling of waters circulating beneath the ice shelf, and freshening of AASW. Thus, as seasonal sea-ice melt and ice shelf supercooling processes played a greater role in enhancing AASW cooling and production on the continental shelf, they would have acted to restrict warmer subsurface water transport onto the continental shelf (Smith et al., 2012) (Fig. 6). Furthermore, the Neoglacial sea-ice increase itself may have been associated with a stabilizing feedback mechanism (which also is not resolved in ice-ocean models) through its role in dampening ocean-induced wave flexural stresses at ice shelf margins, reducing their vulnerability to catastrophic collapse (Massom et al., 2018). We suggest that some combination of the above processes could have acted to slow the rate of Ross Sea grounding line retreat and reduced basal ice shelf melt as indicated by a trend towards more positive $\delta^{2} \mathrm{H}_{\mathrm{FA}}$ values in U1357 between 4.5 and $3 \mathrm{ka}$ (Fig. 4a). Furthermore, large Antarctic ice shelves currently have large zones of marine accreted ice resulting from supercooling (Rignot et al., 2013), thus the signature of $\delta^{2} \mathrm{H}_{\mathrm{FA}}$ is anticipated to become more positive as the ice shelf approaches a steady state of mass balance, relative to the thinning phases when basal melt rates exceed that of accretion. The stabilization of $\delta^{2} \mathrm{H}_{\mathrm{FA}}$ values observed at $3 \mathrm{ka}$ in U1357 suggests the Ross Ice Shelf has maintained a relatively steady state of mass balance since this time.

A recent study implies that the late Holocene shift in coastal versus open water sea-ice patterns in the Ross Sea

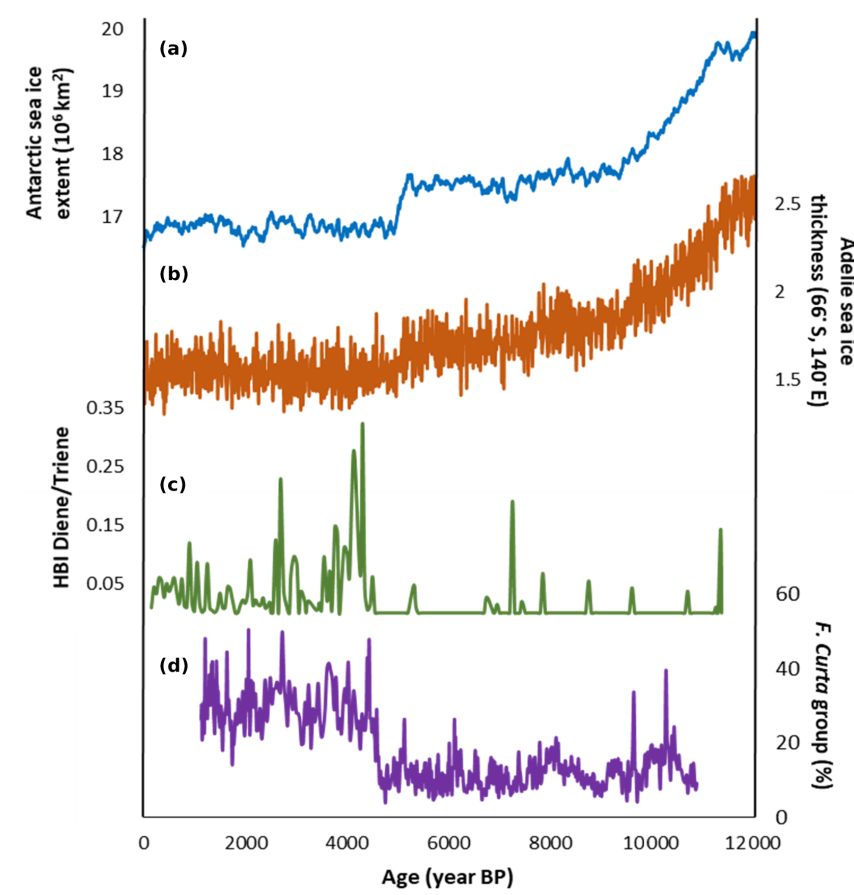

Figure 7. Comparison of sea ice data from the Adélie region with TraCE $21 \mathrm{k}$ simulations. (a) Antarctic sea ice extent $\left(10^{6} \mathrm{~km}^{2}\right)$ from TraCE 21k. (b) Adélie sea ice thickness $\left(66^{\circ} \mathrm{S}, 140^{\circ} \mathrm{E}\right)$ from TraCE $21 \mathrm{k}$. (c) Ratio of the di-unsaturated HBI (C25:2; Diene) and the triunsaturated HBI isomer (C25:3; Triene) at Site U1357. (d) Fragilariopsis curta group relative abundances from MD03 2601.

was driven an increase in katabatic winds since at least $3.6 \mathrm{ka}$ in the Ross Sea (Mezgec et al., 2017), leading to enhanced polynya activity. During colder Antarctic climates, increased latitudinal temperature gradients enhanced katabatic winds in the Ross Sea (Rhodes et al., 2012). This is consistent with our hypothesis, as we interpret this katabatic wind and polynya activity signal to be a response to the preceding Neoglacial cooling at $4.5 \mathrm{ka}$ and evolution of the modern ocean-ice shelf connectivity, which our data suggest was primarily driven by ice shelf cavity expansion. Furthermore, this transition takes place on the background of declining winter insolation (Berger and Loutre, 1991) which would have acted to further enhance and maintain these changes. This insolation decline has previously been hypothesized as a driver of the Neoglacial increase in coastal sea ice in both Prydz Bay and the Adélie Land regions (Denis et al., 2010); however, this monotonic decrease contrasts with the markedly rapid increase in sea ice observed in many records (Fig. 2). Our mechanism of ice shelf cavity expansion, reaching a threshold that promoted significant supercooling of continental shelf water masses, reconciles both the rapidity and timing of Neoglacial onset in the middle Holocene. 


\section{Conclusions and implications for Antarctic climate, sea-ice and ice shelf behaviour}

Our multiproxy record of changing oceanographic conditions in the Adélie Land region indicates a significant meltwater event during the middle Holocene. Comparison of this record with pre-existing studies from around the Antarctic margin indicates this was likely associated with final phases of deglaciation of the Ross Sea embayment. Expansion of the Ross Ice Shelf cavity at this time is proposed to have led to modification of surface water masses formation processes on the continental shelves of Ross Sea and Adélie Land and contributed to widespread Antarctic surface water cooling and increased coastal sea ice during the late Holocene Neoglacial. The lack of these coupled ice-ocean processes is apparent in recent Earth system model experiments, in particular the incorporation of evolving ice shelf cavities, with Trace-21k, for example, instead simulating a decrease in Antarctic sea-ice extent and thickness after 5 ka (Fig. 7). These model outputs are in direct contrast to multiple lines of proxy data in this study and previous work (Steig et al., 1998; Crosta et al., 2008; Denis et al., 2010). Consequently, our results provide insights into the magnitude of this datamodel mismatch, as well as a mechanism for rapid sea-ice change and grounding line stabilization on the background of a warming climate (Liu et al., 2014), both on modern and Holocene timescales. Better representation of the role of evolving ice shelf cavities on oceanic water mass evolution and sea-ice dynamics, which our data indicate acted as a strong negative feedback, will be fundamental to understanding the oceanographic and glaciological implications of future ice shelf loss in the Antarctic.

Data availability. All new data presented in this paper can be found in the Supplement.

Supplement. The supplement related to this article is available online at: https://doi.org/10.5194/cp-17-1-2021-supplement.

Author contributions. KEA, JAB, and RM wrote the paper. JB and OS carried out the fatty acid isotope analysis. AA and RM conducted the grain size analyses. JE and GM generated the HBI data. FJJE measured X-ray fluorescence scanning and electron microscopy. CR conducted the opal measurements. RD, RM, XC, and GM developed the age model. AC ran the model simulations. DPL and EG analysed the Trace-21k experiment data. RD was lead proponent on the U1357 drilling proposal. All authors contributed to the interpretations of data and finalization of the manuscript.

Competing interests. The authors declare that they have no conflict of interest.
Acknowledgements. Samples and data were provided by the International Ocean Discovery Program (IODP). Francisco J. Jimenez-Espejo and Carlota Escutia were funded by the Spanish Ministry of Science and Innovation (grant CTM2017-89711-C2-1P), co-funded by the European Union through FEDER funds. We thank Stefan Schouten, Veronica Willmott, Francesca Sangiorgi, Jaime Toney, and Jennifer Pike for discussions and Veronica Willmott, Heiko Moossen, Anine Hallander, Robert Jamieson and Chris Gallagher for technical support.

Financial support. This research has been supported by the Natural Environment Research Council (CENTA PhD; NE/L002493/1 and Standard Grant Ne/I00646X/1), Japanese Society for the Promotion of Science (JSPS/FF2/60 no. L-11523), NZ Marsden Fund (grant nos. 18-VUW-089 and 15-VUW-131), NSF (grant nos. PLR-1443347 and ACI-1548562), the U.S. Dept. of Energy (grant no. DE-SC0016105), ERC (StG ICEPROXY, 203441; ANR CLIMICE, FP7 Past4Future, 243908), L'Oréal-UNESCO New Zealand For Women in Science Fellowship, University of Otago Research Grant, the IODP U.S. Science Support Program, Spanish Ministry of Science and Innovation (grant no. CTM201789711-C2-1-P), and the European Union (FEDER).

Review statement. This paper was edited by Bjørg Risebrobakken and reviewed by two anonymous referees.

\section{References}

Adcroft, A., Campin, J.-M., Hill, C., and Marshall, J.: Implementation of an Atmosphere-Ocean General Circulation Model on the Expanded Spherical Cube, Mon. Weather Rev., 132, 2845-2863, https://doi.org/10.1175/MWR2823.1, 2004.

Anderson, J. B., Conway, H., Bart, P. J., Witus, A. E., Greenwood, S. L., McKay, R. M., Hall, B. L., Ackert, R. P., Licht, K., Jakobsson, M., and Stone, J. O.: Ross Sea paleo-ice sheet drainage and deglacial history during and since the LGM, Quaternary Sci. Rev., 100, 31-54, https://doi.org/10.1016/j.quascirev.2013.08.020, 2014.

Aoki, S., Kitade, Y., Shimada, K., Ohshima, K. I., Tamura, T., Bajish, C. C., Moteki, M., and Rintoul, S. R.: Widespread freshening in the Seasonal Ice Zone near $140^{\circ} \mathrm{E}$ off the Adélie Land Coast, Antarctica, from 1994 to 2012, J. Geophys. Res.-Ocean., 118, 6046-6063, https://doi.org/10.1002/2013JC009009, 2013.

Arrigo, K. R. and van Dijken, G. L.: Phytoplankton dynamics within 37 Antarctic coastal polynya systems, J. Geophys. Res., 108, 3271, https://doi.org/10.1029/2002JC001739, 2003.

Asper, V. L. and Smith, W. O.: Particle fluxes during austral spring and summer in the southern Ross Sea, Antarctica, J. Geophys. Res.-Ocean., 104, 5345-5359, https://doi.org/10.1029/1998JC900067, 1999.

Baggenstos, D., Severinghaus, J. P., Mulvaney, R., McConnell, J. R., Sigl, M., Maselli, O., Petit, J. R., Grente, B., and Steig, E. J.: A Horizontal Ice Core From Taylor Glacier, Its Implications for Antarctic Climate History, and an Improved Taylor Dome Ice Core Time Scale, Paleoceanogr. Paleoclimatol., 33, 778-794, https://doi.org/10.1029/2017PA003297, 2018. 
Beans, C., Hecq, J. H., Koubbi, P., Vallet, C., Wright, S., and Goffart, A.: A study of the diatom-dominated microplankton summer assemblages in coastal waters from Terre Adelie to the Mertz Glacier, East Antarctica (139-145), Polar Biol., 31, 1101-1117, https://doi.org/10.1007/s00300-008-0452-x, 2008.

Belt, S. T., Massé, G., Rowland, S. J., Poulin, M., Michel, C., and LeBlanc, B.: A novel chemical fossil of palaeo sea ice: IP25, Org. Geochem., 38, 16-27, https://doi.org/10.1016/j.orggeochem.2006.09.013, 2007.

Belt, S. T., Smik, L., Brown, T. A., Kim, J.-H., Rowland, S. J., Allen, C. S., Gal, J.-K., Shin, K.-H., Lee, J. I., and Taylor, K. W. R.: Source identification and distribution reveals the potential of the geochemical Antarctic sea ice proxy IPSO25, Nat. Commun., 7, 12655, https://doi.org/10.1038/ncomms12655, 2016.

Bentley, M. J., Ocofaigh, C., Anderson, J. B., Conway, H., Davies, B., Graham, A. G. C., Hillenbrand, C. D., Hodgson, D. A., Jamieson, S. S. R., Larter, R. D., Mackintosh, A., Smith, J. A., Verleyen, E., Ackert, R. P., Bart, P. J., Berg, S., Brunstein, D., Canals, M., Colhoun, E. A., Crosta, X., Dickens, W. A., Domack, E., Dowdeswell, J. A., Dunbar, R., Ehrmann, W., Evans, J., Favier, V., Fink, D., Fogwill, C. J., Glasser, N. F., Gohl, K., Golledge, N. R., Goodwin, I., Gore, D. B., Greenwood, S. L., Hall, B. L., Hall, K., Hedding, D. W., Hein, A. S., Hocking, E. P., Jakobsson, M., Johnson, J. S., Jomelli, V., Jones, R. S., Klages, J. P., Kristoffersen, Y., Kuhn, G., Leventer, A., Licht, K., Lilly, K., Lindow, J., Livingstone, S. J., Massé, G., McGlone, M. S., McKay, R. M., Melles, M., Miura, H., Mulvaney, R., Nel, W., Nitsche, F. O., O'Brien, P. E., Post, A. L., Roberts, S. J., Saunders, K. M., Selkirk, P. M., Simms, A. R., Spiegel, C., Stolldorf, T. D., Sugden, D. E., van der Putten, N., van Ommen, T., Verfaillie, D., Vyverman, W., Wagner, B., White, D. A., Witus, A. E., and Zwartz, D.: A community-based geological reconstruction of Antarctic Ice Sheet deglaciation since the Last Glacial Maximum, Quaternary Sci. Rev., 100, 1-9, https://doi.org/10.1016/j.quascirev.2014.06.025, 2014.

Berger, A. and Loutre, M. F.: Insolation values for the climate of the last 10 million years, Quaternary Sci. Rev., 10, 297-317, https://doi.org/10.1016/0277-3791(91)90033-Q, 1991.

Bindoff, N. L., Rintoul, S. R., and Massom, R.: Bottom Water formation and polynyas in Adélie Land, Antarctica, R. Soc. Tasmania, 133, 51-56, 2000.

Brook, E. J., White, J. W. C., Schilla, A. S. M., Bender, M. L., Barnett, B., Severinghaus, J. P., Taylor, K. C., Alley, R. B., and Steig, E. J.: Timing of millennial-scale climate change at Siple Dome, West Antarctica, during the last glacial period, Quaternary Sci. Rev., 24, 1333-1343, https://doi.org/10.1016/j.quascirev.2005.02.002, 2005.

Budge, S. M., Wooller, M. J., Springer, A. M., Iverson, S. J., McRoy, C. P., and Divoky, G. J.: Tracing carbon flow in an arctic marine food web using fatty acid-stable isotope analysis, Oecologia, 157, 117-129, https://doi.org/10.1007/s00442-008-1053-7, 2008.

Campagne, P., Crosta, X., Houssais, M. N., Swingedouw, D., Schmidt, S., Martin, A., Devred, E., Capo, S., Marieu, V., Closset, I., and Massé, G.: Glacial ice and atmospheric forcing on the Mertz Glacier Polynya over the past 250 years, Nat. Commun., 6, 6642, https://doi.org/10.1038/ncomms7642, 2015.
Condron, A. and Winsor, P.: Meltwater routing and the Younger Dryas, P. Natl. Acad. Sci. USA, 109, 19928-19933, https://doi.org/10.1073/pnas.1207381109, 2012.

Conway, H., Hall, B. L., Denton, G. H., Gades, A. M., and Waddington, E. D.: Past and Future Grounding-Line Retreat of the West Antarctic Ice Sheet, Science 286, 280-283, https://doi.org/10.1126/science.286.5438.280, 1999.

Crosta, X., Denis, D., and Ther, O.: Sea ice seasonality during the Holocene, Adelie Land, East Antarctica, Mar. Micropaleontol., 66, 222-232, https://doi.org/10.1016/j.marmicro.2007.10.001, 2008.

Dalsgaard, J., St. John, M., Kattner, G., Müller-Navarra, D., and Hagen, W.: Fatty acid trophic markers in the pelagic marine environment, Adv. Mar. Biol., 46, 225-340, https://doi.org/10.1016/S0065-2881(03)46005-7, 2003.

DeMaster, D. J.: The supply and accumulation of silica in the marine environment, Geochim. Cosmochim. Ac., 45, 1715-1732, https://doi.org/10.1016/0016-7037(81)90006-5, 1981.

Denis, D., Crosta, X., Barbara, L., Masse, G., Renssen, H., Ther, O., and Giraudeau, J.: Sea ice and wind variability during the Holocene in East Antarctica: Insight on middlehigh latitude coupling, Quaternary Sci. Rev., 29, 3709-3719, https://doi.org/10.1016/j.quascirev.2010.08.007, 2010.

DiTullio, G. R., Grebmeier, J. M., Arrigo, K. R., Lizotte, M. P., Robinson, D. H., Leventer, A., Barry, J. P., VanWoert, M. L., and Dunbar, R. B.: Rapid and early export of Phaeocystis antarctica blooms in the Ross Sea, Antarctica, Nature, 404, 595-598, https://doi.org/10.1038/35007061, 2000.

Domack, E., Amblàs, D., Gilbert, R., Brachfeld, S., Camerlenghi, A., Rebesco, M., Canals, M., and Urgeles, R.: Subglacial morphology and glacial evolution of the Palmer deep outlet system, Antarctic Peninsula, Geomorphology, 75, 125-142, https://doi.org/10.1016/j.geomorph.2004.06.013, 2006.

Escutia, C., Brinkhuis, H., Klaus, A., and Expedition 318 Scientists: Expedition 318 Summary, https://doi.org/10/1024/iodp.proc.318.101.2011, pp. 101, 2011.

Etourneau, J., Collins, L. G., Willmott, V., Kim, J.-H., Barbara, L., Leventer, A., Schouten, S., Sinninghe Damsté, J. S., Bianchini, A., Klein, V., Crosta, X., and Massé, G.: Holocene climate variations in the western Antarctic Peninsula: evidence for sea ice extent predominantly controlled by changes in insolation and ENSO variability, Clim. Past, 9, 1431-1446, https://doi.org/10.5194/cp-9-1431-2013, 2013.

Feakins, S. J., Warny, S., and Lee, J.-E.: Hydrologic cycling over Antarctica during the middle Miocene warming, Nat. Geosci., 5, 557-560, https://doi.org/10.1038/NGEO1498, 2012.

Folk, R. L. and Ward, W. C.: Brazos River bar [Texas]; a study in the significance of grain size parameters, J. Sediment. Res., 27, 3-26, https://doi.org/10.1306/74D70646-2B21-11D78648000102C1865D, 1957.

Hein, A. S., Marrero, S. M., Woodward, J., Dunning, S. A., Winter, K., Westoby, M. J., Freeman, S. P. H. T., Shanks, R. P., and Sugden, D. E.: Mid-Holocene pulse of thinning in the Weddell Sea sector of the West Antarctic ice sheet, Nat. Commun., 7, 12511, https://doi.org/10.1038/ncomms12511, 2016.

Hellmer, H. H.: Impact of Antarctic ice shelf basal melting on sea ice and deep ocean properties, Geophys. Res. Lett., 31, 1-4, https://doi.org/10.1029/2004GL019506, 2004. 
Hillenbrand, C. D., Smith, J. A., Hodell, D. A., Greaves, M., Poole, C. R., Kender, S., Williams, M., Andersen, T. J., Jernas, P. E., Elderfield, H., Klages, J. P., Roberts, S. J., Gohl, K., Larter, R. D., and Kuhn, G.: West Antarctic Ice Sheet retreat driven by Holocene warm water incursions, Nature, 547, 43-48, https://doi.org/10.1038/nature22995, 2017.

Hodell, D. A., Kanfoush, S. L., Shemesh, A., Crosta, X., Charles, C. D., and Guilderson, T. P.: Abrupt Cooling of Antarctic Surface Waters and Sea Ice Expansion in the South Atlantic Sector of the Southern Ocean at 5000 cal yr B.P., Quaternary Res., 56, 191198, https://doi.org/10.1006/qres.2001.2252, 2001.

Holland, D. M., Jacobs, S. S., and Jenkins, A.: Modelling the ocean circulation beneath the Ross Ice Shelf, Antarct. Sci., 15, 13-23, https://doi.org/10.1017/S0954102003001019, 2003.

Huang, Y., Street-Perrott, F. A., Perrott, R. A., Metzger, P., and Eglinton, G.: Glacial-interglacial environmental changes inferred from molecular and compound-specific $\delta^{13} \mathrm{C}$ analyses of sediments from Sacred Lake, Mt. Kenya, Geochim. Cosmochim. Ac., 63, 1383-1404, https://doi.org/10.1016/S0016-7037(99)00074$5,1999$.

Hughes, K., Langhorne, P. J., Leonard, G. H. and Stevens, C. L.: Extension of an Ice Shelf Water plume model beneath sea ice with application in McMurdo Sound, Antarctica, J. Geophys. Res.-Ocean., 119, 8662-8687, https://doi.org/10.1002/2013JC009411, 2014.

Jacobs, S. S., Giulivi, C. F., and Mele, P. A.: Freshening of the Ross Sea During the Late 20th Century, Science, 297, 386-389, https://doi.org/10.1126/science.1069574, 2002.

Jacobs, S. S., Merle, P. A., Smethie, W. M., and Mortlock, R. A.: Summer Oceanographic Measurements near the Mertz Polynya $\left(140-150^{\circ} \mathrm{E}\right)$ on NB Palmer Cruise 00-08, Tech. Rep. LDEO2003-3, LDEO, 2004.

Jensen, S., Renberg, L., and Reutergårdh, L.: Residue Analysis of Sediment and Sewage Sludge for Organochlorines in the Presence of Elemental Sulfur, Anal. Chem., 49, 316-318, https://doi.org/10.1021/ac50010a033, 1977.

Johns, L., Wraige, E. J., Belt, S. T., Lewis, C. A., Massé, G., Robert, J. M., and Rowland, S. J.: Identification of a C25highly branched isoprenoid (HBI) diene in Antarctic sediments, Antarctic sea-ice diatoms and cultured diatoms, Org. Geochem., 30, 1471-1475, https://doi.org/10.1016/S0146-6380(99)00112-6, 1999.

Jones, J. M., Gille, S. T., Goosse, H., Abram, N. J., Canziani, P. O., Charman, D. J., Clem, K. R., Crosta, X., de Lavergne, C., Eisenman, I., England, M. H., Fogt, R. L., Frankcombe, L. M., Marshall, G. J., Masson-Delmotte, V., Morrison, A. K., Orsi, A. J., Raphael, M. N., Renwick, J. A., Schneider, D. P., Simpkins, G. R., Steig, E. J., Stenni, B., Swingedouw, D., and Vance, T. R.: Assessing recent trends in high-latitude Southern Hemisphere surface climate, Nat. Clim. Change, 6, 917-926, https://doi.org/10.1038/nclimate3103, 2016.

Jourdain, N. C., Mathiot, P., Merino, N., Durand, G., Le Sommer, J., Spence, P., Dutrieux, P., and Madec, G.: Ocean circulation and sea-ice thinning induced bymelting ice shelves in the Amundsen Sea, J. Geophys. Res.-Ocean, 122, 2550-2573, https://doi.org/10.1002/2016JC012509, 2017.

Killops, S. and Killops, V.: Introduction to Organic Geochemistry, John Wiley \& Sons, 2004.

Kim, J. H., Schneider, R. R., Müller, P. J., and Wefer, G.: Interhemispheric comparison of deglacial sea-surface temperature patterns in Atlantic eastern boundary currents, Earth Planet. Sci. Lett., 194, 383-393, https://doi.org/10.1016/S0012-821X(01)00545-3, 2002.

Kim, J. H., van der Meer, J., Schouten, S., Helmke, P., Willmott, V., Sangiorgi, F., Ko, N., Hopmans, E. C., and Damsté, J. S. S.: New indices and calibrations derived from the distribution of crenarchaeal isoprenoid tetraether lipids: Implications for past sea surface temperature reconstructions, Geochim. Cosmochim. Ac., 74, 4639-4654, https://doi.org/10.1016/j.gca.2010.05.027, 2010.

Kingslake, J., Scherer, R. P., Albrecht, T., Coenen, J., Powell, R. D., Reese, R., Stansell, N. D., Tulaczyk, S., Wearing, M. G., and Whitehouse, P. L.: Extensive retreat and re-advance of the West Antarctic Ice Sheet during the Holocene, Nature, 558, 430-434, https://doi.org/10.1038/s41586-018-0208-x, 2018.

Kopczynska, E. E., Goeyens, L., Semeneh, M., and Dehairs, F.: Phytoplankton Composition and Cell Carbon Distribution in Prydz Bay, Antarctica - Relation To Organic Particulate Matter and Its Delta-C-13 Values, J. Plankton Res., 17, 685-707, https://doi.org/10.1093/plankt/17.4.685, 1995.

Kusahara, K., Hasumi, H., and Tamura, T.: Modeling sea ice production and dense shelf water formation in coastal polynyas around East Antarctica, J. Geophys. Res.-Ocean, 115, C10006, https://doi.org/10.1029/2010JC006133, 2010.

Leventer, A., Domack, E. W., Dunbar, R., Pike, J., Stickley, C., Maddison, E., Brachfeld, S., Manley, P., and McClennen, C.: Marine sediment record from the East Antarctic margin reveals dynamics of ice sheet recession, GSA Today, 16, 4-10, https://doi.org/10.1130/GSAT01612A.1, 2006.

Liu, Z., Zhu, J., Rosenthal, Y., Zhang, X., Otto-Bliesner, B. L., Timmermann, A., Smith, R. S., Lohmann, G., Zheng, W., and Timm, O. E.: The Holocene temperature conundrum, P. Natl. Acad. Sci. USA, 111, 3501-3505, https://doi.org/10.1073/pnas.1407229111, 2014.

Lowry, D. P., Golledge, N. R., Bertler, N. A. N., Selwyn Jones, R., and McKay, R.: Deglacial grounding-line retreat in the Ross Embayment, Antarctica, controlled by ocean and atmosphere forcing, Sci. Adv., 5, eaav8754, https://doi.org/10.1126/sciadv.aav8754, 2019.

Mackintosh, A. N., Verleyen, E., O’Brien, P. E., White, D. A., Jones, R. S., McKay, R., Dunbar, R., Gore, D. B., Fink, D., Post, A. L., Miura, H., Leventer, A., Goodwin, I., Hodgson, D. A., Lilly, K., Crosta, X., Golledge, N. R., Wagner, B., Berg, S., van Ommen, T., Zwartz, D., Roberts, S. J., Vyverman, W., and Masse, G.: Retreat history of the East Antarctic Ice Sheet since the Last Glacial Maximum, Quaternary Sci. Rev., 100, 10-30, https://doi.org/10.1016/j.quascirev.2013.07.024, 2014.

Marcott, S. A., Shakun, J. D., Clark, P. U., and Mix, A. C.: A Reconstruction of Regional and Global Temperature for the Past 11,300 Years, Science, 339, 1198-1201, https://doi.org/10.1126/science.1228026, 2013.

Marshall, J., Adcroft, A., Hill, C., Perelman, L., and Heisey, C.: A finite-volume, incompressible Navier Stokes model for studies of the ocean on parallel computers, J. Geophys. Res.-Ocean, 102, 5753-5766, https://doi.org/10.1029/96JC02775, 1997.

Marsland, S. J., Bindoff, N. L., Williams, G. D., and Budd, W. F.: Modeling water mass formation in the Mertz Glacier Polynya and Adlie Depression, East Antarctica, J. Geophys. Res.-Ocean, 109, C11003, https://doi.org/10.1029/2004JC002441, 2004. 
Massé, G., Belt, S. T., Crosta, X., Schmidt, S., Snape, I., Thomas, D. N., and Rowland, S. J.: Highly branched isoprenoids as proxies for variable sea ice conditions in the Southern Ocean, Antarct. Sci., 23, 487-498, https://doi.org/10.1017/S0954102011000381, 2011.

Massom, R. A., Hill, K. L., Lytle, V. I., Worby, A. P., Paget, M. J., and Allison, I.: Effects of regional fast-ice and iceberg distributions on the behaviour of the Mertz Glacier polynya, East Antarctica, Ann. Glaciol., 33, 391-398, https://doi.org/10.3189/172756401781818518, 2001.

Massom, R. A., Scambos, T. A., Bennetts, L. G., Reid, P., Squire, V. A., and Stammerjohn, S. E.: Antarctic ice shelf disintegration triggered by sea ice loss and ocean swell, Nature, 558, 383-389, https://doi.org/10.1038/s41586-018-0212-1, 2018.

Masson-Delmotte, V., Buiron, D., Ekaykin, A., Frezzotti, M., Gallée, H., Jouzel, J., Krinner, G., Landais, A., Motoyama, H., Oerter, H., Pol, K., Pollard, D., Ritz, C., Schlosser, E., Sime, L. C., Sodemann, H., Stenni, B., Uemura, R., and Vimeux, F.: A comparison of the present and last interglacial periods in six Antarctic ice cores, Clim. Past, 7, 397-423, https://doi.org/10.5194/cp-7-397-2011, 2011.

Matsuda, H.: Early diagenesis of fatty acids in lacustrine sediments - III Changes in fatty acid composition in the sediments from a brackish water lake, Geochim. Cosmochim. Ac., 42, 1027-1034, 1978.

Mayer, L. M.: Organic Matter at the Sediment-Water Interface, in: Organic Geochemistry: principles and applications, Springer, Boston, MA, 171-184, 1993.

McCartney, M. S. and Donohue, K. A.: A deep cyclonic gyre in the Australian-Antarctic Basin, Prog. Oceanogr., 75, 675-750, https://doi.org/10.1016/j.pocean.2007.02.008, 2007.

McKay, R., Golledge, N. R., Maas, S., Naish, T., Levy, R., Dunbar, G., and Kuhn, G.: Antarctic marine ice-sheet retreat in the Ross Sea during the early Holocene, Geology, 44, 7-10, https://doi.org/10.1130/G37315.1, 2016.

Meyers, P. A. and Ishiwatari, R.: Lacustrine organic geochemistry - an overview of indicators of organic matter sources and diagenesis in lake sediments, Org. Geochem., 20, 867-900, https://doi.org/10.1016/0146-6380(93)90100-P, 1993.

Mezgec, K., Stenni, B., Crosta, X., Masson-Delmotte, V., Baroni, C., Braida, M., Ciardini, V., Colizza, E., Melis, R., Salvatore, M. C., Severi, M., Scarchilli, C., Traversi, R., Udisti, R., and Frezzotti, M.: Holocene sea ice variability driven by wind and polynya efficiency in the Ross Sea, Nat. Commun., 8, https://doi.org/10.1038/s41467-017-01455-x, 2017.

Nielsen, S. H. H., Hodell, D. A., Kamenov, G., Guilderson, T., and Perfit, M. R.: Origin and significance of ice-rafted detritus in the Atlantic sector of the Southern Ocean, Geochem. Geophys. Geosy., 8, 12, https://doi.org/10.1029/2007GC001618, 2007.

Pagani, M., Pedentchouk, N., Huber, M., Sluijs, A., Schouten, S., Brinkhuis, H., Damsté, J. S. S., Dickens, G. R., Backman, J., Clemens, S., Cronin, T., Eynaud, F., Gattacceca, J., Jakobsson, M., Jordan, R., Kaminski, M., King, J., Koc, N., Martinez, N. C., McInroy, D., Moore, T. C., O’Regan, M., Onodera, J., Pälike, H., Rea, B., Rio, D., Sakamoto, T., Smith, D. C., St John, K. E. K., Suto, I., Suzuki, N., Takahashi, K., Watanabe, M., and Yamamoto, M.: Arctic hydrology during global warming at the Palaeocene/Eocene thermal maximum, Nature, 442, 671-675, https://doi.org/10.1038/nature05043, 2006.
Paolo, F. S., Fricker, H. A., and Padman, L.: Volume loss from Antarctic ice shelves is accelerating, Science, 348, 327-331, https://doi.org/10.1126/science.aaa0940, 2015.

Peña-Molino, B., McCartney, M. S., and Rintoul, S. R.: Direct observations of the Antarctic Slope Current transport at $113^{\circ} \mathrm{E}$, J. Geophys. Res.-Ocean, 121, 7390-7407, https://doi.org/10.1002/2015JC011594, 2016.

Peters, K. E. and Moldowan, J. M.: The biomarker guide: interpreting molecular fossils in petroleum and ancient sediments, Prentice Hall, New Jersey, 1993.

Pollard, D. and Deconto, R. M.: Contribution of Antarctica to past and future sea-level rise, Nature, 531, 591-597, https://doi.org/10.1038/nature17145, 2016.

Potter, J. R. and Paren, J. G.: Interaction between ice shelf and ocean in George VI Sound, Antarctica, in: Oceanology of the Antarctic Continental Shelf, edited by: Jacobs, S., 35-58, Washington, D.C., American Geophysical Union, 1985.

Rhodes, R. H., Bertler, N. A. N., Baker, J. A., Steen-Larsen, H. C., Sneed, S. B., Morgenstern, U., and Johnsen, S. J.: Little Ice Age climate and oceanic conditions of the Ross Sea, Antarctica from a coastal ice core record, Clim. Past, 8, 1223-1238, https://doi.org/10.5194/cp-8-1223-2012, 2012.

Riaux-Gobin, C., Poulin, M., Dieckmann, G., Labrune, C., and Vétion, G.: Spring phytoplankton onset after the ice break-up and sea-ice signature (Adélie Land, East Antarctica), Polar Res., 30, 5910, https://doi.org/10.3402/polar.v30i0.5910, 2011.

Riaux-Gobin, C., Dieckmann, G. S., Poulin, M., Neveux, J., Labrune, C., and Vétion, G.: Environmental conditions, particle flux and sympagic microalgal succession in spring before the sea-ice break-up in Adélie Land, East Antarctica, Polar Res., 32, 1-25, https://doi.org/10.3402/polar.v32i0.19675, 2013.

Rignot, E., Jacobs, S., Mouginot, J., and Scheuchl, B.: Ice Shelf Melting Around Antarctica, Science, 341, 266-270, https://doi.org/10.1126/science.1235798, 2013.

Riis, V. and Babel, W.: Removal of sulfur interfering in the analysis of organochlorines by GC-ECD, Analyst, 124, 1771-1773, https://doi.org/10.1039/a907504f, 1999.

Robinson, N. J., Williams, M. J. M., Stevens, C. L., Langhorne, P. J., and Haskell, T. G.: Evolution of a supercooled Ice Shelf Water plume with an actively growing subice platelet matrix, J. Geophys. Res.-Ocean, 119, 3425-3446, https://doi.org/10.1002/2013JC009399, 2014.

Sachse, D., Billault, I., Bowen, G. J., Chikaraishi, Y., Dawson, T. E., Feakins, S. J., Freeman, K. H., Magill, C. R., McInerney, F. A., van der Meer, M. T. J. J., Polissar, P., Robins, R. J., Sachs, J. P., Schmidt, H.-L., Sessions, A. L., White, J. W. C., West, J. B., and Kahmen, A.: Molecular paleohydrology: interpreting the hydrogen-isotopic composition of lipid biomarkers from photosynthesizing organisms, Annu. Rev. Earth Planet. Sci., 40, 221-249, https://doi.org/10.1146/annurev-earth042711-105535, 2012.

Schmidt, G. A., Bigg, G. R., and Rohling, E. J.: Global Seawater Oxygen-18 Database - v1.22, available at: https://data.giss.nasa gov/o18data/ (last access: 10 December 2019), 1999.

Schoemann, V., Becquevort, S., Stefels, J., Rousseau, V., and Lancelot, C.: Phaeocystis blooms in the global ocean and their controlling mechanisms: A review, J. Sea Res., 53, 43-66, https://doi.org/10.1016/j.seares.2004.01.008, 2005. 
Schouten, S., Ossebaar, J., Schreiber, K., Kienhuis, M. V. M., Langer, G., Benthien, A., and Bijma, J.: The effect of temperature, salinity and growth rate on the stable hydrogen isotopic composition of long chain alkenones produced by Emiliania huxleyi and Gephyrocapsa oceanica, Biogeosciences, 3, 113-119, https://doi.org/10.5194/bg-3-113-2006, 2006.

Sessions, A. L., Burgoyne, T. W., Schimmelmann, A., and Hayes, J. M.: Fractionation of hydrogen isotopes in lipid biosynthesis, Org. Geochem., 30, 1193-1200, https://doi.org/10.1016/S01466380(99)00094-7, 1999.

Sessions, A. L., Sylva, S. P., Summons, R. E., and Hayes, J. M.: Isotopic exchange of carbon-bound hydrogen over geologic timescales, Geochim. Cosmochim. Ac., 68, 1545-1559, https://doi.org/10.1016/j.gca.2003.06.004, 2004.

Shackleton, N. J. and Kennett, J. P.: Paleotemperature history of the Cenozoic and the initiation of Antarctic glaciation, Oxygen and carbon isotope analyses in DSDP sites 277, 279 and 281, Initial Reports Deep Sea Drilling Project, 29, 743-755, https://doi.org/10.2973/dsdp.proc.37.1977, 1975.

Smethie, W. M. and Jacobs, S. S.: Circulation and melting under the Ross Ice Shelf: Estimates from evolving CFC, salinity and temperature fields in the Ross Sea, Deep Sea Res. Pt. I, 52, 959 978, https://doi.org/10.1016/j.dsr.2004.11.016, 2005.

Smik, L., Belt, S. T., Lieser, J. L., Armand, L. K., and Leventer, A.: Distributions of highly branched isoprenoid alkenes and other algal lipids in surface waters from East Antarctica: Further insights for biomarker-based paleo sea-ice reconstruction, Org. Geochem., 95, 71-80, https://doi.org/10.1016/j.orggeochem.2016.02.011, 2016.

Smith Jr., W. O., Sedwick, P. N., Arrigo, K. R., Ainley, D. G., and Orsi, A. H.: the Ross Sea in a Sea of Change, Oceanography, 25, 90-103, 2012.

Solomina, O. N., Bradley, R. S., Hodgson, D. A., IvyOchs, S., Jomelli, V., Mackintosh, A. N., Nesje, A., Owen, L. A., Wanner, H., Wiles, G. C., and Young, N. E.: Holocene glacier fluctuations, Quaternary Sci. Rev., 111, 9-34, https://doi.org/10.1016/j.quascirev.2014.11.018, 2015.
Spector, P., Stone, J., Cowdery, S. G., Hall, B., Conway, H., and Bromley, G.: Rapid early-Holocene deglaciation in the Ross Sea, Antarctica, Geophys. Res. Lett., 44, 7817-7825, https://doi.org/10.1002/2017GL074216, 2017.

Steig, E. J., Hart, C., White, J., Cunningham, W., Davis, M., and Saltzman, E.: Changes in climate, ocean and ice sheet conditions in the Ross Embayment at 6ka, Ann. Glaciol., 27, 305-310, https://doi.org/10.3198/1998AoG27-1-305-310, 1998.

Strickland, J. D. and Parsons, T. R.: A Practical Handbook of Seawater Analysis, Ottawa, Fisheries Research Board of Canada, Internationale Revue der gesamten Hydrobiologie und Hydrographie, 55, 167-167, 1970.

Todd, C., Stone, J., Conway, H., Hall, B., and Bromley, G.: Late Quaternary evolution of Reedy Glacier, Antarctica, Quaternary Sci. Rev., 29, 1328-1341, https://doi.org/10.1016/j.quascirev.2010.02.001, 2010.

Turner, J., Scott Hosking, J., Marshall, G. J., Phillips, T., and Bracegirdle, T. J.: Antarctic sea ice increase consistent with intrinsic variability of the Amundsen sea low, Clim. Dynam., 46, 23912402, https://doi.org/10.1007/s00382-015-2708-9, 2016.

Whitworth, T., Orsi, A. H., Kim, S.-J., Nowlin, W. D., and Locarnini, R. A.: Water masses and mixing near the Antarctic slope front, in: Ocean, Ice, and Atmosphere: Interactions at the Antarctic Continental Margin, edited by: Jacobs, S. S. and Weiss, R. F., pp. 1-27, 1998.

Wong, W. W. and Sackett, W. M.: Fractionation of stable carbon isotopes by marine phytoplankton, Geochim. Cosmochim. Ac., 42, 1809-1815, https://doi.org/10.1016/0016-7037(78)90236-3, 1978.

Zhang, J. and Hibler, W. D.: On an efficient numerical method for modeling sea ice dynamics, J. Geophys. Res., 102, 8691, https://doi.org/10.1029/96JC03744, 1997.

Zhang, Z., Sachs, J. P., and Marchetti, A.: Hydrogen isotope fractionation in freshwater and marine algae: II. Temperature and nitrogen limited growth rate effects, Org. Geochem., 40, 428-439, https://doi.org/10.1016/j.orggeochem.2008.11.002, 2009. 